\title{
Project Development and Data Programs for Assessing the Quality of the Willamette River, Oregon
}

River-Quality Assessment of the Willamette River Basin, Oregon

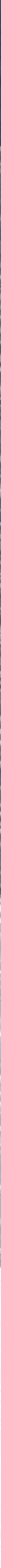





\section{Project Development and Data Programs for Assessing the Quality of the Willamette River, Oregon}

By David A. Rickert, Walter G. Hines, and Stuart W. McKenzie

GEOLOGICAL SURVEY CIRCULAR 715-C 


\section{United States Department of the Interior}

THOMAS S. KLEPPE, Secretary

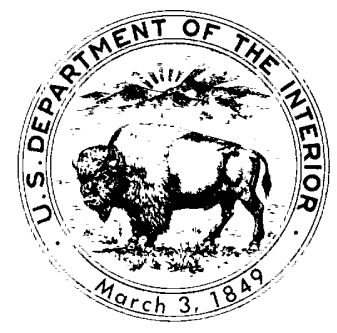

\section{Geological Survey}

V. E. McKelvey, Director

Rickert, David A. 1940-

Project development and data programs for assessing the quality of the Willamette River, Oregon. (River-quality assessment of the Willamette River Basin, Oregon)

(Geological Survey Circular 715-C)

Bibliography: p. 30-31.

1. Water quality-Oregon-Willamette River. I. Hines, Walter G., joint author. II.

McKenzie, Stuart W., joint author. III. Title. IV. Series. V. Series: United

States Geological Survey Circular 715-C.

QE75.C5 no. 715-C [TD224.07] 363.6'1 76-608207 


\section{FOREWORD}

The American public has identified the enhancement and protection of river quality as an important national goal, and recent laws have given this commitment considerable force. As a consequence, a considerable investment has been made in the past few years to improve the quality of the Nation's rivers. Further improvements will require substantial expenditures and the consumption of large amounts of energy. For these reasons, it is important that alternative plans for river-quality management be scientifically assessed in terms of their relative ability to produce environmental benefits. To aid this endeavor, this circular series presents a case history of an intensive river-quality assessment in the Willamette River basin, Oregon.

The series examines approaches to and results of critical aspects of riverquality assessment. The first several circulars describe approaches for providing technically sound, timely information for river-basin planning and management. Specific topics include practical approaches to mathematical modeling, analysis of river hydrology, analysis of earth resources-river quality relations, and development of data-collection programs for assessing specific problems. The later circulars describe the application of approaches to existing or potential river-quality problems in the Willamette River basin. Specific topics include maintenance of high-level dissolved oxygen in the river, effects of reservoir release patterns on downstream river quality, algal growth potential, distribution of toxic metals, and the significance of erosion potential to proposed future land and water uses.

Each circular is the product of a study devoted to developing resource information for general use. The circulars are written to be informative and useful to informed laymen, resource planners, and resource scientists. This design stems from the recognition that the ultimate success of river-quality assessment depends on the clarity and utility of approaches and results as well as their basic scientific validity.

Individual circulars will be published in an alphabetical sequence in the Geological Survey Circular 715 series entitled "River-Quality Assessment of the Willamette River Basin, Oregon."

J. S. Cragwall, Jr.

Chief Hydrologist 
Cover: Willamette River as it winds through Portland, Oregon. Photograph taken by Hugh Ackroyd. 


\section{CONTENTS}

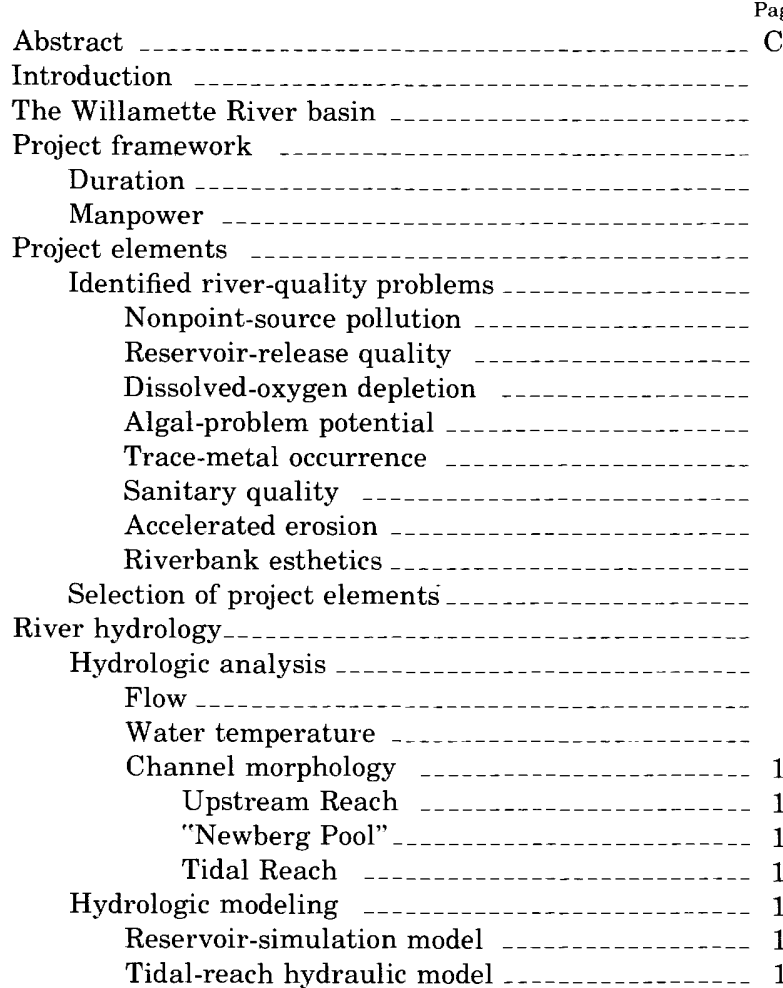

The approach for obtaining appropriate data $\ldots \ldots \ldots$ Matching methods and data programs to assess selected problems
Dissolved-oxygen deletion _........_. 16
The method-mathematical modeling _..._- 16
Model configuration
Critical period -
Calibration and verification _...- 17

Data program _._. 18

Deficiencies of monitoring and surveillance data

Role of existing data
Matching methods and data programs to assess Page selected problems-Continued

Dissolved-oxygen deletion-Continued

Data program-Continued

Premodeling reconnaissance

Data program for calibration and verifica-

tion -......- 19

Rationale for the data program _..._-_ 20

Impact of land-use activity on erosion and river qual- 20 ity

The method-interpretive mapping _._._. 20

Basis_........ 22

Presenting the results

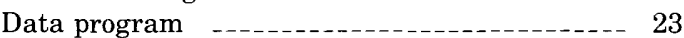

False-color-IR photography _...-_-_-_ 23

Photomosaic base _._. 23

Terrain property data

Climate -...... 24

Slope

Geology _.

Soils _...... 24

Runoff _._._. 24

Comparative roles of existing and new data

Potential for algal problems _....._-_-_._-_._- 24

Infeasibility of mathematical modeling _.....-. 24

The method-descriptive assessment _...___._ 25

Data program _.... 25

Role of existing data

Reconnaissance _._._._._._. 26

Intensive studies _.......- 26

Rationale for the data program _..._._. 26

Trace-metal occurrence _._._._-_._-_._-_._-_._. 26

The method-_descriptive assessment ______- 26

Sampling medium

Distinction between natural background and pollution _._._. 27

Data program _._- 27

Rationale for the data program

Summary and conclusions _._._. 28

Acknowledgments

References _.

\section{ILLUSTRATIONS}

Figure 1. Map of the Willamette River basin emphasizing main stem, tributaries, and reservoirs

2. Graphs showing Willamette River discharge at Salem, Oreg., 1944, 1964, and 1973 water years

3. Graphs showing mean monthly and maximum and minimum daily temperatures for three sites on the North Santiam, Willamette, and South Yamhill Rivers, Oreg.

4. Map and diagram representing the Willamette River, Oreg., showing distinctive hydrologic reaches, and elevation profile. 
FIGURE 5. Graphs showing typical channel cross sections of the Willamette River, Oreg., at concurrent low-flow conditions

6. Schematic showing the lower Willamette River system C13

7. Schematic showing the process of assessing the impacts of land-use activity on erosion and river quality

\section{TABLES}

TABLE 1. Existing or potential river-quality problems: Willamette River basin, Oreg.

2. Selected information for major reservoirs in the Willamette River basin, Oreg.

3. Selected physical characteristics of the main stem Willamette River, Oreg. -

\section{CONVERSION FACTORS}

\begin{tabular}{|c|c|c|}
\hline English & Multiply by & Metric (SI) \\
\hline $\mathrm{ft}$ (feet) & $3.048 \times 10^{-1}$ & m (metres) \\
\hline $\mathrm{ft} / \mathrm{s}$ (feet per second) & $3.048 \times 10^{-1}$ & $\mathrm{~m} / \mathrm{s}$ (metres per second) \\
\hline $\mathrm{ft} / \mathrm{mi}$ (feet per mile) & $1.894 \times 10^{-1}$ & $\mathrm{~m} / \mathrm{km}$ (metres per kilometre) \\
\hline $\mathrm{ft} /$ acre (feet per acre) & $7.532 \times 10^{-1}$ & $\mathrm{~m} / \mathrm{hm}^{2}$ (metres per square hectometre) \\
\hline $\mathrm{ft}^{3} / \mathrm{s}$ (cubic feet per second) & $2.832 \times 10^{-2}$ & $\mathrm{~m}^{3} / \mathrm{s}$ (cubic metres per second) \\
\hline acres & $4.047 \times 10^{-1}$ & $\mathrm{hm}^{2}$ (square hectometres) \\
\hline acre-ft (acre-feet) & $1.233 \times 10^{-3}$ & $\mathrm{hm}^{3}$ (cubic hectometres) \\
\hline mi (miles) & 1.609 & km (kilometres) \\
\hline $\mathrm{mi}^{2}$ (square miles) & 2.590 & $\mathrm{~km}^{2}$ (square kilometres) \\
\hline
\end{tabular}




\title{
Project Development and Data Programs for Assessing the Quality of the Willamette River, Oregon
}

\author{
By David A. Rickert, Walter G. Hines, \\ and Stuart W. McKenzie
}

\begin{abstract}
The U.S. Geological Survey recently (1976) completed an intensive river-quality assessment in the Willamette River basin, Oregon. The objectives were to (1) define a practical framework for conducting comprehensive river-quality assessments; (2) determine the kinds and amounts of data required to adequately assess various types of river-quality problems; (3) develop techniques for evaluating such data and for presenting it so as to promote better public understanding of its significance; (4) develop and document methods for evaluating basin-development alternatives in terms of potential impacts on river quality; and (5) apply the framework, data, and methods to assess the existing or potential riverquality problems of the Willamette River basin.

This circular covers aspects of the five objectives by examining overall project development and the methods and data programs used to assess four river-quality problems. The assessed problems were (1) the effect of population and industrial growth and resulting waste discharges on dissolved oxygen, (2) the potentially harmful effects on land and river quality of accelerated erosion resulting from intensified land use, (3) the potential for nuisance algal growths, and (4) the possibility of trace-metal accumulation in river-bottom sediments.

This circular describes the approaches and rationales used to organize the project, to select and formulate the assessment methods, and to design the data programs. The purpose is to provide in-depth information on project development and design as an aid and stimulus for others who are interested in river-quality assessment.
\end{abstract}

\section{INTRODUCTION}

Virtually all forms of growth and development exert some impact on river quality. Achievement of desirable river quality at acceptable cost requires that management decisions be based on sound impact assessments, not on arbitrary assumptions. Thus, the vital link between resource-development plans and management decisions is scientific assessment to predict the probable impacts of each planning alternative. At present, river-quality assessment is the Achilles' heel of the overall process. The difficulty in appraising impacts results from (1) the absence of a rational framework for structuring such work, (2) the lack, poor development, and misapplication of assessment methods, and (3) the scarcity of reliable data.

To develop a unified approach for river-quality assessment the U.S. Geological Survey recently conducted a prototype study of the Willamette River basin, Oregon. The objectives were to (1) define a practical framework for conducting comprehensive river-quality assessments; (2) determine the kinds and amounts of data required to adequately assess various types of river-quality problems; (3) develop techniques for evaluating such data and for presenting it so as to promote better public understanding of its significance; (4) develop and document methods for evaluating basin-development alternatives in terms of potential impacts on river quality; and (5) apply the framework, data, and methods to assess the most important existing or potential river-quality problems of the Willamette River basin.

To meet the first objective, the initial circular of this series (Rickert and Hines, 1975) presented a seven-step practical framework for conducting comprehensive river-quality assessments. The present circular covers aspects of all five objectives by examining overall project development and the methods and data programs used to assess four river-quality problems. The specific problems were (1) the effect of population and industrial growth and resulting waste discharges on dissolved oxygen (DO), (2) the potentially harmful effects on land and river quality of accel- 
erated erosion resulting from intensified land use, (3) the potential for nuisance algal growths, and (4) the possibility of trace-metal accumulation in river-bottom sediments. The goal of the assessment program, and thus the context of the methods and data programs, was to provide technically sound, appropriate, and adequate information for land-use and water-resource planning.

This circular is based on an unpublished work plan and includes information and knowledge developed during the first 2 years of the study. The various sections describe the approaches and rationales used to organize the project, select and formulate the assessment methods, and design the data programs.

The information is intended for use by both the scientific and planning communities. The data programs may be of particular interest to State and regional resource-planning agencies as a basis for designing in-house programs to assess specific problems, and for evaluating the suitability of programs proposed by Federal agencies and consulting firms. The approach and method sections should be useful to specialists in the environmental-science community who are interested in becoming involved in interdisciplinary, problem-solving programs. All the information should have high transfer value to other studies, because the problems being assessed in the Willamette are common to many of the $\mathrm{Na}$ tion's rivers.

\section{THE WILLAMETTE RIVER BASIN}

The Willamette River basin, a watershed of nearly $11,500 \mathrm{mi}^{2}\left(29,800 \mathrm{~km}^{2}\right.$ ) (fig. 1), is located in northwestern Oregon between the Cascade and Coast Ranges. Within the basin are the State's three largest cities, Portland, Salem, and Eugene, and approximately 1.4 million people, representing 70 percent of the State's population ( 1970 census). The basin supports an economy based on timber, agriculture, industry, and recreation, and contains extensive fish and wildlife habitats.

The Willamette River basin is roughly rectangular, with a north-south length of about $150 \mathrm{mi}$ $(240 \mathrm{~km})$ and an east-west width of $75 \mathrm{mi}(120$ $\mathrm{km})$. Altitudes vary from less than $10 \mathrm{ft}(3 \mathrm{~m})$ near the mouth of the Willamette River, to $450 \mathrm{ft}$ $(140 \mathrm{~m})$ on the valley floor near Eugene, and to more than $10,000 \mathrm{ft}(3,050 \mathrm{~m})$ in the Cascade
Range. The Coast Range generally varies in average altitude from 1,000 to $2,000 \mathrm{ft}(300-600 \mathrm{~m})$ but includes peaks higher than $4,000 \mathrm{ft}(1,200 \mathrm{~m})$.

The slopes and foothills of the Cascade Range account for more than 60 percent of the basin area. About 62 percent of the basin is timberland located largely in the tributary basins (Gleeson, 1972). Approximately 33 percent of the area is farmland, and the remaining 5 percent is urbanized and in other uses.

The main stem Willamette River forms at the confluence of the Coast and Middle Forks south of Eugene and flows northward for $187 \mathrm{mi}(301 \mathrm{~km})$ through the $3,500 \mathrm{mi}^{2}\left(9,100 \mathrm{~km}^{2}\right)$ Willamette Valley floor. The first $135 \mathrm{mi}(217 \mathrm{~km})$ of the river is characterized by a meandering channel. Through most of the remaining $52 \mathrm{mi}(84 \mathrm{~km})$, the Willamette flows within well-defined banks, unhindered by falls or rapids except for the basaltic intrusion at Oregon City which creates the Willamette Falls. The $26.5 \mathrm{mi}(42.6 \mathrm{~km})$ reach below the falls is subject to nonsaline tidal effects, transmitted from the Pacific via the Columbia River. The Willamette empties into the Columbia at a point which is $99 \mathrm{mi}(160 \mathrm{~km})$ from the Pacific Ocean.

Historically, the Willamette River experienced acute water-quality problems related primarily to summer low-flow and heavy organic-waste loading from cities and pulp and paper mills. In recent years, low-flow augmentation from storage reservoirs and the basinwide advent of secondary wastewater treatment have markedly improved the quality of the river. However, in light of expected urban and industrial growth, decisionmakers are now involved with evaluating alternatives for keeping future river-quality conditions at the present high levels.

The Willamette River basin was selected for the prototype study for several reasons. First, there was an excellent base of background data, particularly on hydrology. Second, the social and political attitudes in Oregon reflected a keen interest in environmental quality. This suggested that the people and agencies would welcome the study and that results would be used at the State and local levels. Third, a river-basin management plan already existed, as did several land-use projections (Willamette Basin Task Force, Main Report, 1969). Thus, the study could evaluate exist- 


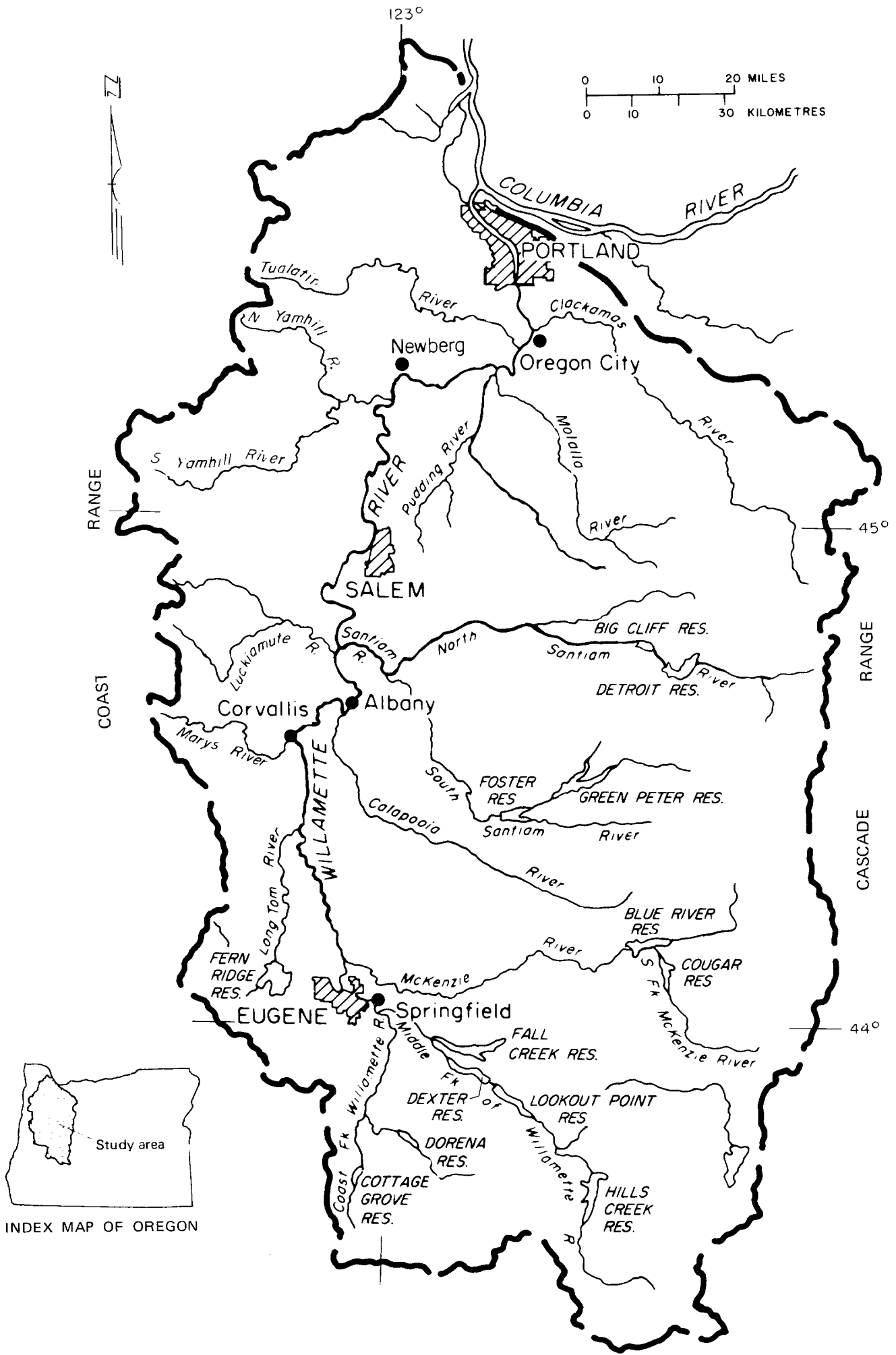

FIGURE 1.-Willamette River basin, Oregon. 
ing planning alternatives to provide a realistic test of assessment approaches. Fourth, the Willamette was the largest river in the Nation on which all major point-source discharges received secondary waste-water treatment (Oregon Department of Environmental Quality, 1970). The quality was above the stringent State standards, and the river was considered a national success story (Gleeson, 1972). Thus, the study would be able to appraise the factors to which past improvement was attributed while evaluating the management options for maintaining or improving the quality.

\section{PROJECT FRAMEWORK}

\section{DURATION}

The time required to conduct a useful assessment of river quality is a compromise between taking enough time to do a sound and comprehensive scientific study and so much time that results become irrelevant to the decisionmaking process. The compromise initially selected for the prototype Willamette study was 2 years, beginning in January 1973 . The original concept was to use 6 months for planning and for organizing field and laboratory programs, 12 months for collecting and analyzing data and the writing of initial reports, and 6 months for completing the analysis of data and the final reports.

After the first 2 months it became obvious that assessment of certain river-quality problems would require extending data collection into the fall of the second year. Thus, it would be impossible to reduce the data collected during this time interval and to have it incorporated into final reports. On this basis, the study duration was expanded to $2 \frac{1}{2}$ years.

In retrospect, $2 \frac{11}{2}$ years appears to be a reasonable period for intensive, practical assessment of river-quality problems. This duration provides time for (1) identification of specific river-quality problems, (2) project planning prior to initiation of fieldwork, (3) 1 full year of fieldwork, and (4) the opportunity to recheck specific problems in the field during the most critical time period of the annual cycle. In many river basins (including the Willamette) summer is the critical time period for most river-quality problems. For such basins a study duration of $2 \frac{1}{2}$ years, together with a January start, provides for two summer field seasons. River-quality studies longer than
$2 \frac{1}{2}-3$ years begin to lose their usefulness to the resource-planning process. Specific critical problems may require assessment over longer periods, but initial assessments of immediate problems need to be completed. As noted in a previous circular (Rickert and Hines, 1975), reappraisals can then be made under reduced time pressures, while full scale updates can be scheduled on a periodic basis.

\section{MANPOWER}

The nature of river-quality problems requires an interdisciplinary, team-oriented assessment. In the Willamette study the discipline categories included hydrology, sanitary chemistry, aquatic biology, mathematical modeling, geology, and air-photointerpretation. The project team was composed of four individuals having different professional backgrounds, together with five parttime aides. Analytical work was done by the project team and by several Geological Survey laboratories. In addition, the project periodically used the talents of the Water Resources Division's research staffs and District offices, as well as the consultative, fieldwork, and laboratory inputs of scientists from several universities.

\section{PROJECT ELEMENTS}

Specific work elements for the program were determined through discussions with State, interstate, and Federal agencies concerned with the management of river quality. The discussions proceeded over the first 4 months of the project to identify eight existing or potential river-quality problems. These problems were then evaluated using data and information from the Oregon Department of Environmental Quality (1970, and unpublished), the Geological Survey (1962-73, 1964-73) and the STORET system of the U.S. Environmental Protection Agency (Sayers, 1971). Next, in conjunction with the concerned agencies, the problems were ranked in order of their relative importance to resource management (table 1). This section briefly outlines each of the eight problems and provides rationales for the assigned rankings of importance.

\section{IDENTIFIED RIVER-QUALITY PROBLEMS}

NONPOINT-SOURCE POLLLTION

Knowledge of nonpoint sources of pollution is a critical information need for effective river- 
quality management. In the Willamette River basin, considerable general knowledge was available on nonpoint sources, but information was lacking on quantitative loadings and their effects.

Potential nonpoint sources of concern in the basin included (1) land-use activities such as logging, construction, and agriculture, (2) irrigation return flow, (3) urban runoff, (4) navigation, (5) gravel and navigat ional dredging, and (6) benthal oxygen-demanding deposits in Portland Harbor.

Of these six items, existing concern over the sediment problems arising from intensive land use caused this topic to be listed as a separate problem in table 1 . In addition, possible benthal deposits in Portland Harbor were considered under the problem category of DO depletion. In contrast, navigation, together with gravel and navigational dredging, were only of minor concern to planners as potential sources of pollution.

The remaining two items were irrigation and urban runoff. Nearly half a million acres $\left(2.0 \times 10^{5} \mathrm{hm}^{2}\right)$ are irrigated in the basin, and water volumes average about 2.3 feet of water per acre $\left(1.7 \mathrm{~m} / \mathrm{hm}^{2}\right)$ per season. However, irrigation is almost exclusively by sprinkler and therefore, involves practically no surface runoff. Hence, there is virtually no transport of suspended or dissolved solids to the river from this activity and no detectable impact on river quality.

On a yearly basis, urban runoff undoubtedly washes large tonnages of contaminants into the Willamette River system. However, the summers are extremely dry in the Willamette River basin, and nearly all the annual precipitation occurs during the months of October through March. Moreoever, the winter and spring rains tend to be continuous and gentle, rather than intense. These patterns suggest that most of the oxygendemanding materials and nutrients that enter the Willamette from urban runoff are probably washed from the river prior to the low-flow, high-

TABLE 1.-Existing or potential river-quality problems: Willamette River basin, Oreg.

\begin{tabular}{lc}
\multicolumn{1}{c}{ Problem } & $\begin{array}{c}\text { Relature } \\
\text { importance }\end{array}$ \\
Nonpoint-source pollution & 3 \\
Reservoir-release quality & 3 \\
Dissolved-oxygen depletion & 1 \\
Algal-problem potential & 2 \\
Trace-metal occurrence & 1 \\
Sanitary quality & \\
Accelerated erosion & \\
Riverbank esthetics &
\end{tabular}

*1 = greatest importance; $3=$ least importance. temperature summer period when biological river-quality problems are most likely to occur.

Concern was voiced over the possibility that urban runoff and other sources might be causing a buildup of toxic metals in the Willamette. However, this information need was already covered under the problem category of trace-metal occurrence.

Following numerous discussions, it was decided that those aspects of nonpoint sources not covered under other topics were relatively unimportant to assessment of major river-quality problems in the Willamette. Accordingly, the category was assigned a relative importance of 3 .

\section{RESERVOIR-RELEASE QUALITY}

Reservoir releases represent potential point sources of pollution to any river system. Early discussion with planning officials indicated concern that reservoir releases could possibly affect the turbidity, temperature, and nutrient content of the Willamette River. The concern existed primarily because water is sometimes released from lower levels of certain reservoirs instead of from the surface. Such water would be low in temperature and possibly high in turbidity and nutrient concentrations.

Existing records from various sources were analyzed to determine possible impacts of reservoir releases on the quality of the Willamette. The data indicated that the reservoirs do not contribute any significant long-term turbidity to the river. Similarly, although cool-water releases do occur, the tributary streams quickly warm to ambient water temperatures because of rapid mixing resulting from steep gradients and high turbulence. Water temperatures in the main stem of the Willamette apparently are only slightly affected by releases of cold reservoir water.

Existing records did show spring and fall upsurges of phosphorus concentrations in the Willamette. Such upsurges are consistent with a pattern of reservoir turnover and known release patterns. This problem needed attention but was included under the problem category of algal-problem potential. The category of reservoir-release quality was consequently ranked as a priority 3 item.

\section{DISSOLVED-OXYGEN DEPLETION}

Historically, maintenance of high DO content 
has been the critical problem in the Willamette River. During summer low-flow periods, the DO content in Portland Harbor often went to zero (Velz, 1961; Gleeson, 1972), and for years, low DO levels inhibited the fall migration of salmon from the Columbia River.

In recent years, summer DO levels have increased dramatically (Rickert, Hines, and McKenzie, 1976). The improvement has resulted from a reduction in the loading of biochemical oxygen demand (BOD), coupled with streamflow augmentation from storage reservoirs. However, the Oregon Department of Environmental Quality (DEQ) still considers the maintenance of high DO levels to be the factor of highest priority in planning the Willamette's future. At the time of the study, long-range planning was especially timely, because DEQ anticipated (Oregon Department of Environmental Quality, 1970) that DO conditions would peak in 1972 with the application of secondary treatment to all major municipal and industrial wastes. Because of the immense importance of DO to long-range planning, the problem was given a number 1 priority.

\section{ALGAL-PROBLEM POTENTIAL}

In the Willamette River, a potential for excessive algal growth may exist because nitrogen and phosphorus loadings are increasing, whereas carbon loading (measured as BOD) is decreasing (Gleeson, 1972). The decrease in carbon loading has resulted from the application of secondary treatment to all major sources of organic wastes. The nitrogen and phosphorus levels remain high because both nutrients are ineffectively removed by standard secondary treatment and because nitrogen is present in very high concentrations in certain industrial wastes.

Despite the high nitrogen and phosphorus concentrations in the Willamette, excessive growths of algae have not been observed. The reason might be any one of several including trace-metal limitations, unfavorable water temperatures, high summertime turbidities, or short, water detention times. On the other hand, the environment in the Willamette could possibly be approaching a condition in which large, problemcausing growths of algae might begin to occur. Recent work in the Upper Potomac Estuary suggests that the initiation of secondary treatment may cause ecological shifts in receiving waters and actually stimulate the growth of nui- sance blue-green algae (Jaworski, Lear, and Villa, 1971). Concern about preventing future algal problems in the Willamette resulted in this problem category receiving a priority 2 ranking.

\section{TRACE-METAL OCCLRRENCE}

Many materials discharged into river systems are toxic to aquatic organisms when present in critical concentrations. These materials include numerous trace metals and manmade organic compounds such as insecticides, polychlorinated biphenyls (PCB's), herbicides, and certain industrial organics. Even though such materials are usually discharged to rivers at subtoxic levels, many are capable of being concentrated at successive steps in aquatic-food chains in a process called "biological magnification."

An approach for evaluating sublethal toxicity conditions is badly needed for the purpose of long-range river-basin planning. However, research is just beginning to relate the characteristics of biological communities to the contents of toxic materials in water, sediment, and aquaticfood chains. The work began only recently because scientists previously lacked the techniques to accurately determine low levels of the metals and organics. Now, the major problem is how to sample the environment so the results are reliable. This will take many years to resolve and will involve studying the life cycles of many aquatic organisms to determine when and how specific ones can be used as toxicity indicators.

In lieu of definitive studies, it is useful to develop background information on the levels of toxic materials in river water, bottom sediments, and aquatic organisms. Review of industrialdischarge records in the Willamette Basin indicates that there is little possibility of toxic industrial organics entering the Willamette River. Furthermore, over the past 10 years, "hard" (persistent) pesticides have not been used in the basin for disease vector control nor for widespread plant-pest control.

In contrast, there are several industrial sources of potentially toxic trace metals in addition to the metals that undoubtedly enter the river in urban runoff. Thus, if a toxicity problem occurred, it would probably result from accumulation of trace metals. Existing records provided no data on the distribution of trace metals in the Willamette River system. Such information was needed for a 
comprehensive evaluation of river quality and, accordingly, an assessment of trace-metal occurence was assigned a relative importance of 1 .

\section{SANITARY QUALITY}

Coliform bacteria levels in the Willamette River exceed the State standard of 1,000 organisms per $100 \mathrm{ml}$ over most of the annual cycle. This occurs in spite of high levels of waste-water treatment and the disinfection of all treatmentplant effluents. Median coliform counts range mostly from 2,500 to 3,500 during summer, lowflow conditions, but the numbers increase at high flows.

The Oregon DEQ (Oregon Department of Environmental Quality, 1970) has identified two major sources of enteric bacteria in addition to waste-water treatment plants. One is rapid bacterial growth in organic solutions from certain industrial effluents. The other is land runoff, especially urban and agricultural storm drainage. The fact that coliform counts increase with flow indicates that land runoff has a major influence on bacterial populations. DEQ notes that coliforms from both of these major sources are mostly nonfecal and, presumably, should have little if any, public-health significance. Although sanitary quality in the Willamette requires further study, the problem was given a number 3 priority because of the apparent nonfecal origin of the bacterial populations.

\section{ACCELERATED EROSION}

Projections for the Willamette Valley indicate a great increase in population and industry over the next 50 years. Large acreages of land now in forest or agricultural use will be urbanized. In addition, vast areas of forest land will be logged for Oregon's pulp and paper industries. At present, the potential impact of these activities on land and river quality is virtually unknown.

What is known is that the Willamette at high flow is very turbid and that man's activities, such as logging, construction, and agriculture, are primarily responsible (Willamette Basin Task Force, Appendix G, 1969). The economic costs include dredging (especially Portland Harbor) for navigation, increased costs of treating water supplies, and the loss of spawning and feeding areas for fish. In addition, man's activities in the basin sometimes trigger large-scale land defor- mations such as landslides, slumps, and gullies. Such deformations often ruin the land for further intended use and result in large costs for cleanup and restoration. The deformations also release additional quantities of sediment to tributary streams and thus eventually to the main stem.

The situation in the Willamette is now such that either land-use activity and land runoff are brought into the planning picture or else the ultimate reality may be land-imposed constraints on river quality. An integrated assessment is needed of how different uses of land and water may affect the quality of these resources. The first requirement for this type of assessment is a method for delineating the erosional impacts associated with different land-use activities on different types of terrain. The critical nature of this problem resulted in a priority ranking of 1 .

\section{RIVERBANK ESTHETICS}

Oregon is presently engaged in a Greenway Plan to protect open space along the Willamette and to give the residents of the valley access to the water and wildlife. The Greenway was originally conceived as a continuous parkland along both banks of the river. However, realities of funding, legislation, and land-use needs have changed the concept to a more modest proposal for a series of intermittent parks (Council on Environmental Quality, 1973). The question therefore arises of how to determine which parcels of land are most suitable for inclusion in the Greenway system. Although such decisions require the balancing of numerous factors, one prominent factor is riverbank esthetics. The visual impact of the river and related landscapes largely determines the value of land as open space and the enjoyment that people receive from its use.

Thus, delineation of riverbank esthetics is presently a prominent problem of the Willamette River. To determine the value of land as open space, a system is needed to evaluate the factors that contribute to landscape esthetics. Leopold (1969) has devised a system which first identifies relevant landscape features that influence esthetic impression and then uses these features to rank the relative uniqueness of different sites. A ranking of sites based on this or a similar system could be done for the Willamette. Because of the need, the category was assigned a relative importance of 2 . 
The selection of project elements was completed by analyzing the priority list (table 1) in terms of ability to produce useful information within the boundaries of time, funding, and manpower. All three priority 1 problems were selected as project elements, whereas the three priority 3 problems were rejected. Both priority 2 items were considered for inclusion over a period of several months, but, finally, on the basis of available manpower, algal-problem potential was included and riverbank esthetics was rejected.

In summary, the four project elements were as follows:

1. Dissolved-oxygen depletion

2. Impact of land-use activity on erosion and river quality

3. Potential for algal problems

4. Trace-metal occurrence

The next task of project development was to define and analyze those major hydrologic factors that influence the four selected problems. With the exception of land-related analyses for the erosional element, the hydrologic analyses were focused on the main stem of the Willamette, beginning at Eugene. Tributaries were treated primarily as inputs to the main stem.

\section{RIVER HYDROLOGY}

Hydrologic characteristics determine the physical dynamics of rivers, which, in turn, control the occurrence and extent of chemical and biological processes (Velz, 1970; Hines, Rickert and McKenzie, 1976). Because of this control, analysis of river hydrology is a prerequisite to selecting a method or identifying the data needed to assess a river-quality problem. Only through such analysis can we understand the inherent (background) variability in river quality that results from natural variations in hydrology. Once this understanding is attained, the impacts of man on the basin can be examined independently of natural variations.

Thorough analysis of existing hydrologic data was the first technical step of the Willamette study. Data from several sources (U.S. Geological Survey, 1962-73; Willamette Basin Task Force, Appendix B, 1969; Velz, 1951, 1961) were collated and then analyzed to provide a basis for designing the data-collection programs needed to assess the four project elements.

\section{HYDROLOGIC ANALYSIS}

\section{FLOW}

Most of the flow in the Willamette occurs in the period November to March as a result of persistent winter rainstorms and spring snowmelt. Post-March snowmelt in the high Cascade Range often prolongs seasonal runoff into June or early July. These patterns of flow are illustrated by the hydrographs in figure 2. The 1944 hydrograph is typical of natural runoff patterns prior to largescale reservoir regulation (considered to be pre1953), whereas the 1964 and 1973 hydrographs reflect postregulation patterns. Three reservoirs began operation on tributaries in the Coast Range and Calapooya Mountains (see fig. 1.) in the period between 1941 and 1949. However, it was not until operation of reservoirs on Cascade Range tributaries, beginning in water year 1954, that reservoirs had a significant impact on Willamette River flow. Table 2 summarizes information on the major Willamette Basin reservoirs, including the initial dates of flow regulation.

Reservoir regulation has had a profound impact on low flows in the Willamette (Hines, Rickert, and McKenzie, 1976). Marked increases have occurred in the 1-, 3-, 7-, 14-, and 30-day low flows during the post-1952 period. Reservoir regulation has also tended to curtail the length of the period of low flow, typically from about mid-July through mid-October before regulation, to about mid-July through mid- or late-August following regulation. This condition occurs because the reservoirs, as recently operated, release extra water in the early fall to enhance anadromous fish runs.

\section{WATER TEMPERATURE}

As typified in figure 3, streams and rivers draining the Cascade Range have cooler temperatures than those draining the Coast Range. The large Cascade tributaries, the McKenzie, Santiam, and Clackamas Rivers, are cool because they originate at high altitude where springs and snowmelt contribute to the flow and where air temperatures are cooler than in the Coast Range or on the valley floor. The Cascade Range tributaries also have larger volumes of flow which tend to maintain the cooler temperatures downstream.

Water temperatures in the Willamette and all major tributaries reach a maximum during the July-August period that coincides with the onset 

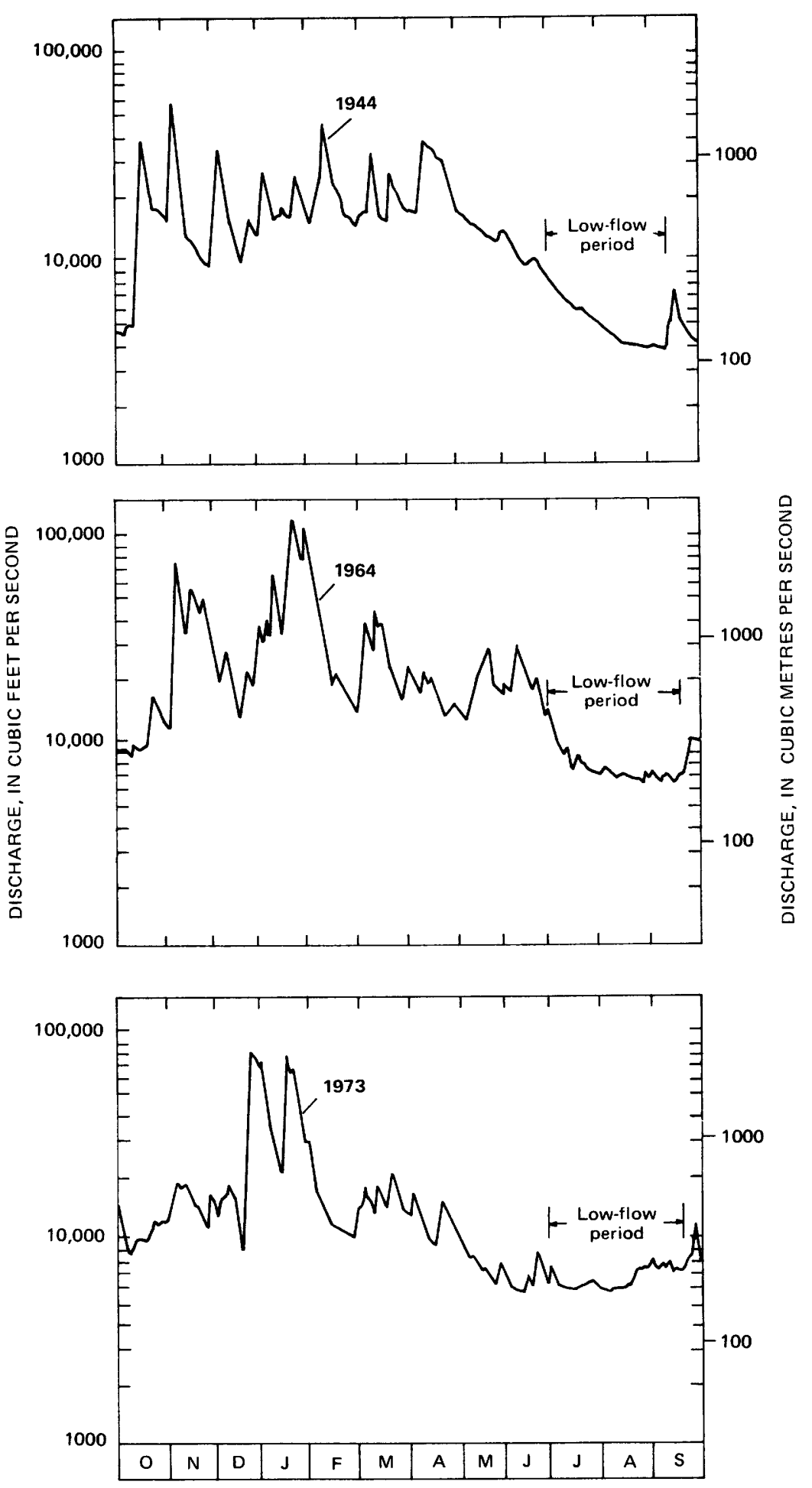

Figure 2.-Willamette River discharge at Salem, Oreg., 1944, 1964, and 1973 water years.

of low-flow conditions. The coincident occurrence $\mid$ to river-quality conditions, particularly DO of high temperature and low flow make the levels.

July-August period the most critical with regard Spatial patterns of water temperatures in the 


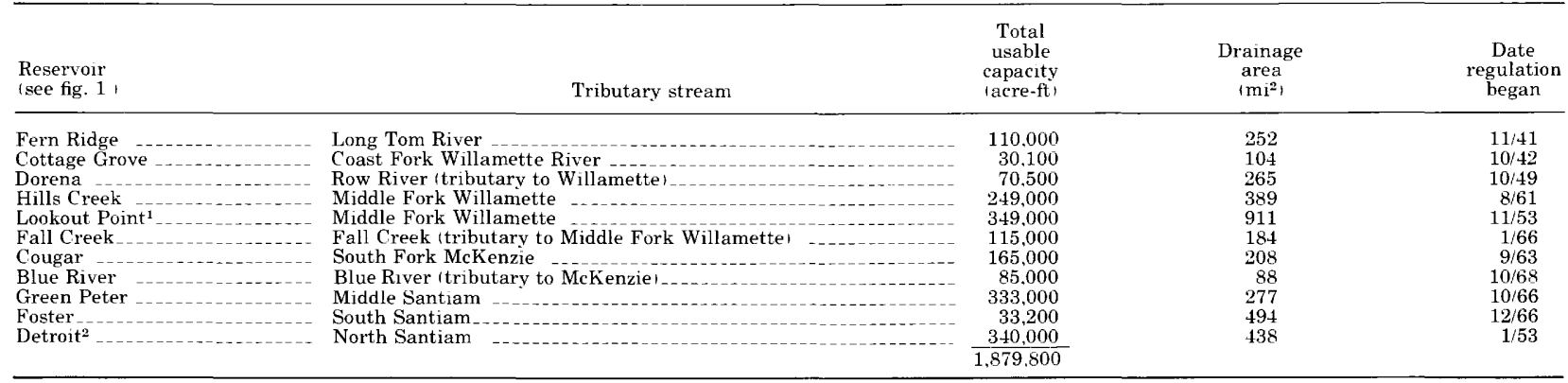

1 Dexter Reservoir, a small reregulating reservoir, is located just downstream.

${ }^{2} \mathrm{Big}$ Cliff Reservoir, a small reregulating reservoir, is located just downstream.

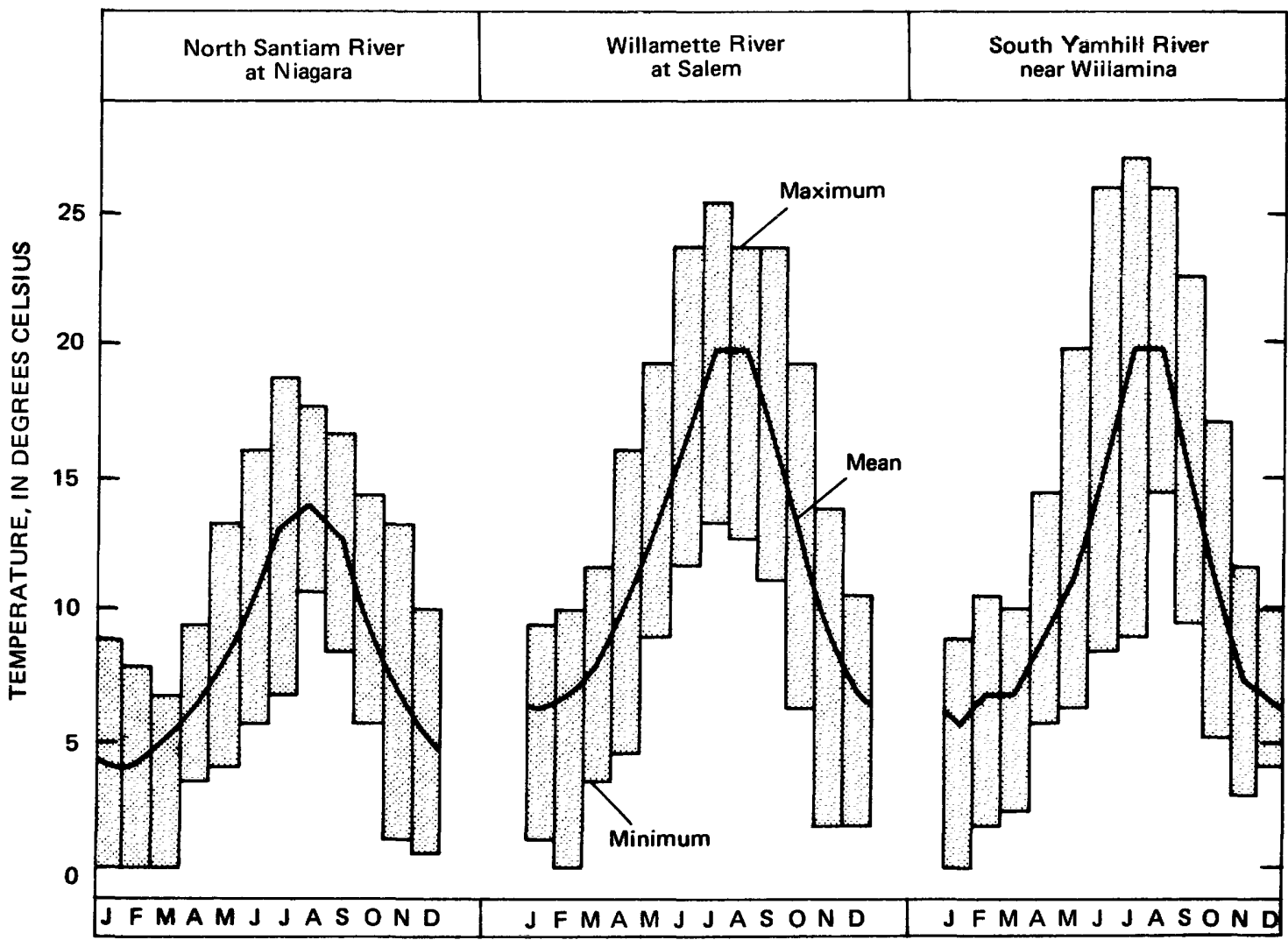

Figure 3.-Mean monthly and maximum and minimum daily water temperatures for the North Santiam, Willamette, and South Yamhill Rivers, Oreg.

Willamette have been analyzed by the Willamette Basin Task Force (Appendix B, 1969). For the July-August period, the results indicate that water temperatures increase in the downstream direction. The results suggest that reservoir regulation has only a slight impact on the temperature regimen of the Willamette. The subreach above Albany (see fig. 1) often has lower tempera- tures than would be expected because of the influence of cool, bottom-release waters from the Lookout Point-Dexter Reservoir complex on the Middle Fork (see table 2). However, reservoirs on the other tributaries are apparently far enough upstream to allow cold release waters to reach ambient temperature before confluence with the Willamette. 
The Willamette River is composed of three distinctive reaches whose morphologic characteristics partly govern both the hydraulics of flow and river-quality behavior. Pertinent data for each of the three reaches are included in figures 4 and 5 and in table 3 .

\section{UPSTREAM REACH}

The Upstream Reach, stretching for $135 \mathrm{mi}$ $(217 \mathrm{~km})$ from Eugene to above Newberg, is characterized by a meandering channel. The river is shallow (table 3), and the bed is composed almost entirely of cobbles and gravel which, during summer, are covered with biological growth.

Although the U.S. Army Corps of Engineers has straightened the course of this reach considerably, there are still numerous meanders, islands, and side channels. At low flow, gravel bars are visible, and, in some places, the river is so shallow that small pleasure boats occasionally run aground.

During the low-flow conditions, average stream velocity in the Upstream Reach is seven times that of either of the two downstream reaches (table 3). During floods, velocities are sufficiently high to transport large quantities of cobbles and gravel as bedload. Morphologically this upstream section of the Willamette is an "eroding" reach.

\footnotetext{
"NEWBERG POOL"
}

The "Newberg Pool" extends from just above Newberg down to Willamette Falls, a distance of $25.5 \mathrm{mi}(41.1 \mathrm{~km}$ ). The pool is deep (fig. 5), slow moving, and hydraulically can be characterized as a large stilling basin behind a weir (Willamette Falls). As evidenced by the elevation profile (fig. 4), low velocity, and the presence of fine bottom sediments, the pool is a depositional reach.

Comparison of time-of-travel data (table 3) with those compiled by Velz (1951) suggest that dredging and gravel mining during the last 25 years have significantly increased low-flow traveltimes in the pool (about 30 percent at 7,000 $\mathrm{ft}^{3} / \mathrm{s}$ or $198 \mathrm{~m}^{3} / \mathrm{s}$ ).

During summer, most of the flow that reaches Willamette Falls is diverted through powergeneration turbines or over a fish ladder. These diversion activities can cause mild fluctuations in water levels and flow velocities throughout the entire length of the pool.
The Tidal Reach, covering the lower $26.5 \mathrm{mi}$ $(42.6 \mathrm{~km})$ of the river, is affected by tides and, during spring and early summer, by backwater from the Columbia River (Velz, 1961). The Tidal Reach is extensively dredged to maintain a 40 foot ( $12 \mathrm{~m}$ ) deep navigation channel (fig. 5) from the mouth to about RM 14. The subreach between RM's 5 and 14 is a busy shipping corridor known locally as "Portland Harbor."

During low flows, net downstream movement is relatively slow in this reach, but tidal effects cause flow reversals twice daily and large changes in velocity. Low-flow hydraulics are most complex in the lower $10 \mathrm{mi}(16 \mathrm{~km})$ (fig. 6) where, depending on hourly changes in tide and river stage, Willamette River water may move downstream or Columbia River water may move upstream. The Columbia River water has a slightly higher concentration of dissolved solids and is commonly several degrees cooler than Willamette water. Columbia water is, therefore, denser than Willamette water and, during part of each day (during low flows), moves upstream as a distinct bottom wedge to the vicinity of the St. Johns Bridge (RM 6). The subsequent downstream movement of mixed water is very complex. Depending on slight variations in tide and flows in the two rivers, the downstream discharge may be out the mouth of the Willamette, through Multnomah Channel (see fig. 6), or a combination of the two.

Owing to morphological characteristics and hydraulic conditions, the subreach between RM's 10 and 3 is the primary depositional area of the Willamette River system.

\section{HYDROLOGIC MODELING}

Collation of existing hydrologic data was the necessary first step for designing the data programs needed to assess the quality of the Willamette River. The collated basic data were also used to help analyze the collated river-quality data, to assess the impacts of alternative resource plans, and to format the final reports. However, additional hydrologic information was needed to adequately assess the impact of planning alternatives on future river quality. The most critical needs were information on (1) future low-flow quantities and frequencies and (2) the character of flow and velocities in the hydraulically complex lower $10 \mathrm{mi}(16 \mathrm{~km})$ of the river. These needs 


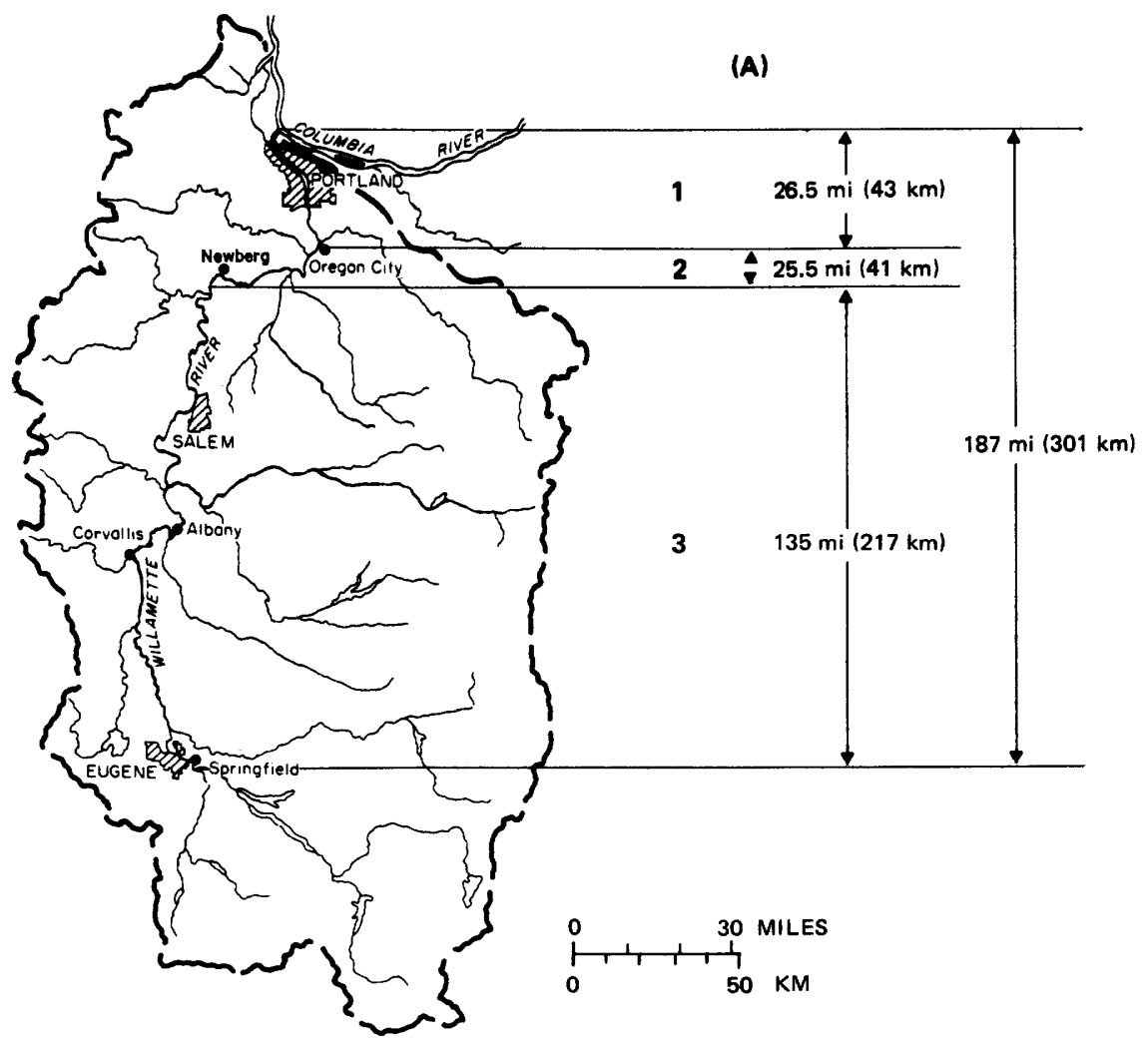

(B)

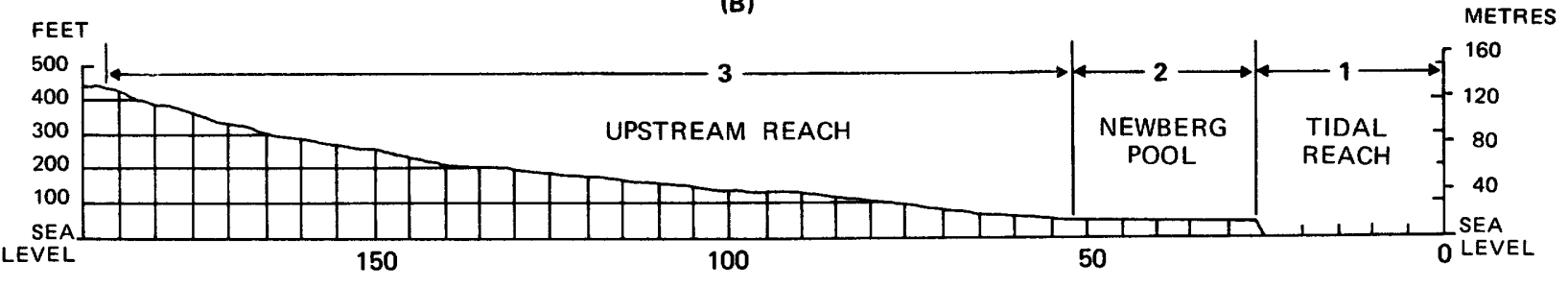

DISTANCE, IN RIVER MILES ABOVE MOUTH

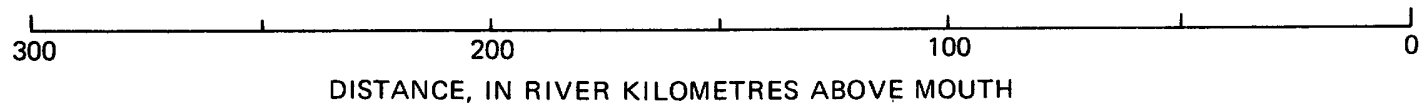

Figure 4.-Willamette River, Oreg., A, Distinctive hydrologic reaches. B, Elevation profile.

TABLE 3. Selected physical characteristics of the main stem Willamette River, Oreg.

[Characteristics refer to summer low-flow conditions of $6 \times 10^{3} \mathrm{ft}^{3} / \mathrm{s}$ at Salem]

\begin{tabular}{|c|c|c|c|c|c|c|c|}
\hline $\begin{array}{l}\text { Reach } \\
\text { (see fig. 4) }\end{array}$ & & $\begin{array}{l}\text { Length } \\
(\mathrm{mi})\end{array}$ & $\begin{array}{l}\text { Approximate } \\
\text { bed slope } \\
(\mathrm{ft} / \mathrm{mi})\end{array}$ & Bed material & $\begin{array}{c}\text { Representative } \\
\text { midchannel } \\
\text { water depth } \\
\text { (ft) }\end{array}$ & $\begin{array}{l}\text { Average } \\
\text { velocity } \\
\text { (ft/s) }\end{array}$ & $\begin{array}{c}\text { Approximate } \\
\text { traveltime } \\
\text { in reach } \\
\text { (days) }\end{array}$ \\
\hline $\begin{array}{l}\text { Tidal Reach } \\
\text { Newberg Pool }\end{array}$ & (1). & $\begin{array}{l}26.5 \\
25.5\end{array}$ & $<0.1$ & Intermixed clay, sand, and gravel. & 40 & ${ }^{10} 0.16$ & 10.0 \\
\hline Upstream Reach & (3). & 135 & $\begin{array}{l}.12 \\
2.8\end{array}$ & $\begin{array}{l}\text { Intermixed clay, sand, and gravel } \\
\text { with some cobbles. } \\
\text { Mostly cobbles and gravel. }\end{array}$ & $\begin{array}{r}25 \\
7\end{array}$ & $\begin{array}{l}10.40 \\
22.9\end{array}$ & $\begin{array}{l}3.9 \\
2.8\end{array}$ \\
\hline
\end{tabular}

${ }^{1}$ Calculated by volume displacement method using channel cross-sectional data

${ }^{2}$ Calculated from dye study by Geologizal Survey (Harris, 1968 ).

required the development of predictive mathe- $\mid$ data inputs are briefly outlined in the following matical models. The modeling approaches and the two sections. 

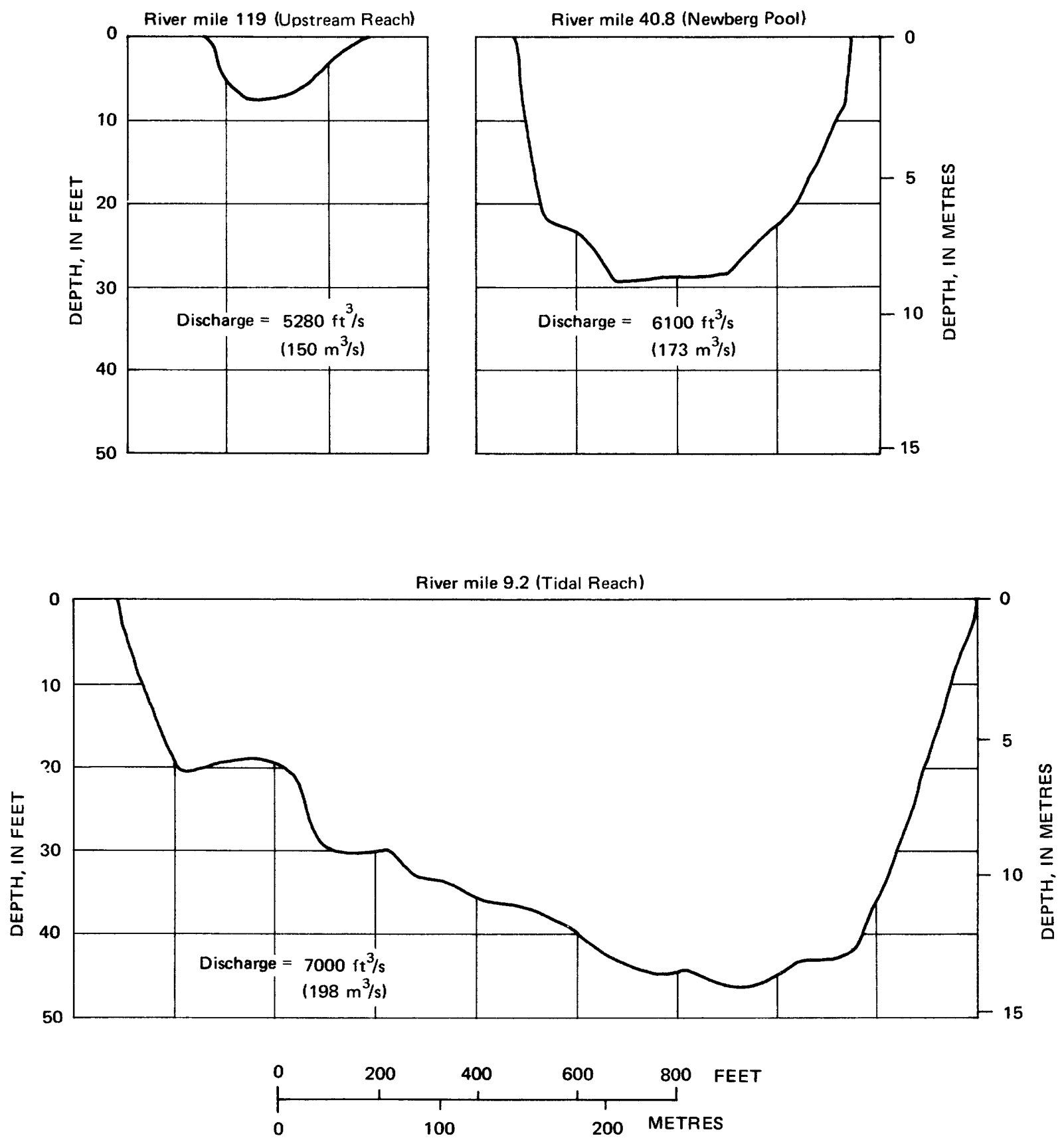

FIGURE 5.-Typical channel cross sections of the Willamette River, Oreg., at concurrent low-flow conditions. The large downstream increases in width and depth greatly affect the hydraulics of flow and, thereby, partly determine the reach-by-reach potential for different types of river-quality problems.

\section{RESERVOIR SIMULATION MODEL}

As noted in table 2, there are 11 major reservoirs in the Willamette River basin with a combined usable capacity of nearly 1.9 million acre-ft $\left(2300 \mathrm{hm}^{3}\right)$. The reservoirs are designed for multipurpose use, but their primary legal function is the maintenance of a minimum navigable depth in the Willamette. The required minimum flow for navigation is $6,000 \mathrm{ft}^{3} / \mathrm{s}\left(170 \mathrm{~m}^{3} / \mathrm{s}\right)$, Salem gage. Other uses of the reservoirs and reservoir water include power generation, onsite recreation, flood protection, maintenance of adequate streamflow for anadromous fish propagation, irri- 
$123^{\circ} 45^{\prime}$

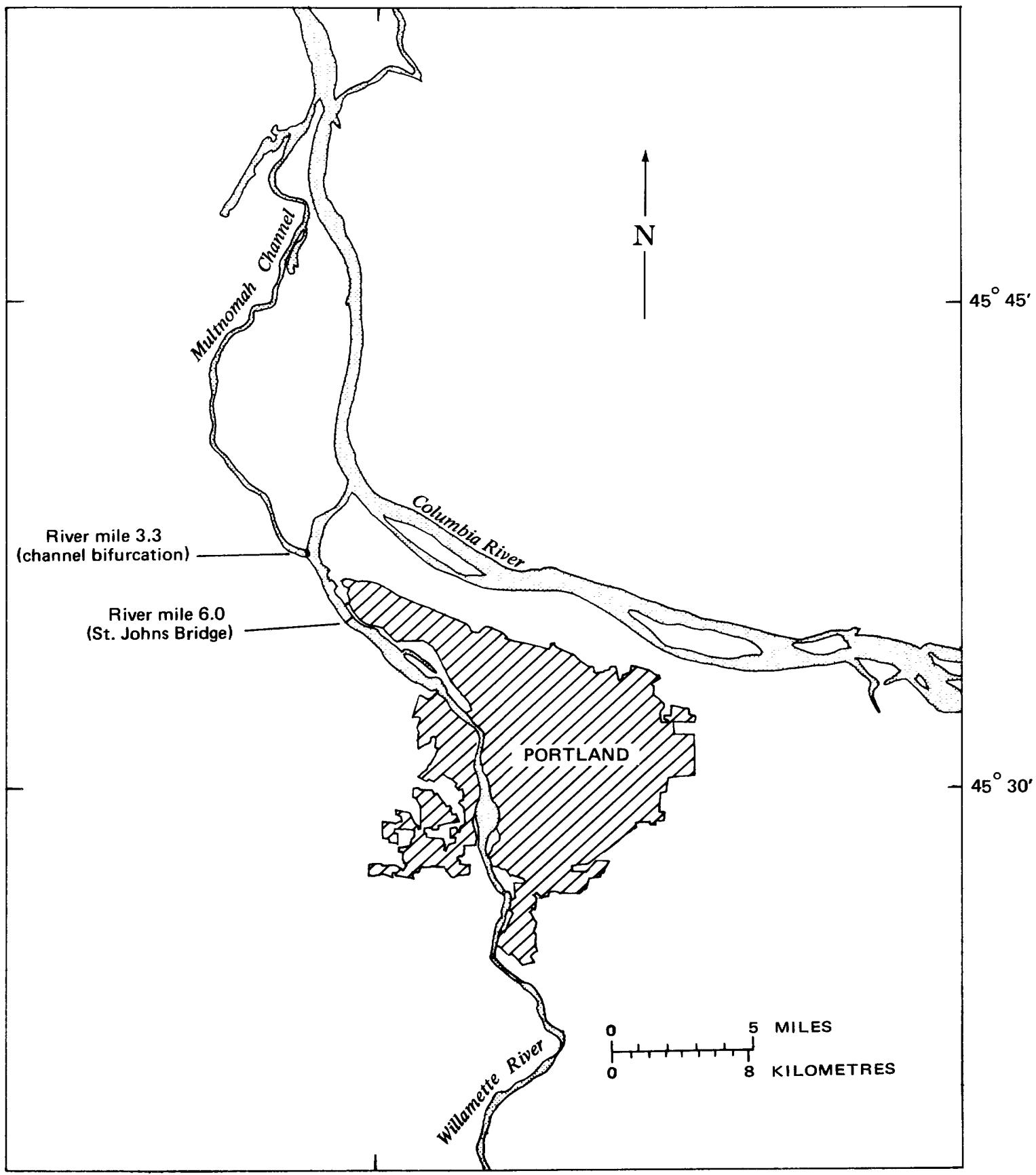

FIGURE 6.-Lower Willamette River system. During low-flow conditions at floodtide, Columbia River water commonly moves upstream beyond St. Johns Bridge as a distinct bottom wedge of denser water. Depending on slight variations in tides and river flows, the subsequent discharge of mixed Columbia-Willamette water may be out the mouth of the Willamette, through Multnomah Channel, or a combination of the two.

gation, and flow augmentation for water-quality enhancement. The latter use is not explicitly planned but occurs as a result of summertime releases made for the other purposes.
The objective of the reservoir simulation model was to provide estimates of the future low-flow magnitudes and frequencies in the Willamette as a basis for assessing alternative plans for river- 
quality management (Sherman, 1976). Specifically, the model was developed to help answer three important questions:

1. What role has past flow augmentation played in bringing the Willamette to its present good quality?

2. What is the predicted magnitude-frequency relationship of summer flows under present reservoir-operating procedures and river-water diversions?

3. What is the predicted magnitude-frequency relationship of summer flows for the next 50 years under present reservoir-operating procedures and anticipated river-water diversions?

The model could also be used to assess the impact on low flow of alternative procedures for reservoir operation and, in addition, to assess the effect of potential new reservoirs.

The HEC-3 computer program of the U.S. Army Corps of Engineers (1968) was selected for the modeling task. This model performs multireservoir routings based on flow requirements at various contrbl points throughout the river system, while maintaining a specified storage balance among the reservoirs. Because low-flow statistics at Salem reveal a strong relationship between 7-and 30-day low flows, it was decided to simulate reservoir operations on a monthly basis. Monthly values are adequate for long-range planning, and the use of monthly rather than daily flows greatly reduced the complexity and cost of modeling.

Data required to verify and use the model included information on unregulated flow; regulated flow; reservoir evaporation; and past, present, and future diversions. The approach for obtaining time sequences of unregulated flows was to correlate flows measured prior to regulation at each reservoir inflow station with flows at stations that have remained unregulated. The calculated relationships were used to estimate what reservoir inflows would have been under unregulated conditions up through 1973. Evaporation data for the model were estimated from a previously developed relation between evaporation and mean monthly temperature. Diversion data were scarce and represented the weakest link in the model.

TIDAL-REACH HYDRAULIC MODEL

Before river quality could be assessed quantitatively in Portland Harbor, the hydraulic charac- teristics of the tidally affected lower $26.5 \mathrm{mi}(42.6$ $\mathrm{km}$ ) of the Willamette (see fig. 6) needed to be defined. A hydraulic model of the lower river was developed to provide this definition (Bennett, 1975).

Inputs to the model included the channel geometry of the Tidal Reach and Multnomah Channel, time histories of stage at the outfalls of the Willamette River and Multnomah Channel on the Columbia, and discharge at two locations in the Willamette River and at one location in Multnomah Channel.

Data collection for model calibration involved synchronized water-surface elevation monitoring over 4- to 5-day periods at several points on the Willamette, the Columbia, and in Multnomah Channel. Data were collected at four different combinations of flow conditions in the Willamette and Columbia Rivers (for example, high Willamette flow, low Columbia flow; low Willamette flow, high Columbia flow). Verification was based on the ability of the model to predict flow velocity and depth during four different 12.5-hour tidal cycles as measured at the two stations on the Willamette and the one station in Multnomah Channel.

The model outputs are velocity and depth of flow at any point in the Tidal Reach and Multnomah Channel. The model is dynamic because velocity and depth can be simulated for any assumed conditions of tide and discharge in the Columbia and Willamette Rivers.

\section{THE APPROACH FOR OBTAINING APPROPRIATE DATA}

Valid data are a fundamental necessity for sound resource assessment. The kinds and amounts of data required to assess a river-quality problem depend primarily on the complexity of the problem, the areal extent of study, and the nature of the method chosen for assessment.

In the Willamette study, the data required to assess the four priority problems (see "Selection of Project Elements") were obtained through a four-step approach:

1. Identify the types of data required to assess each problem.

2. Collate and analyze pertinent existing data. Where these data appear insufficient to assess the problem adequately, proceed to step 3.

3. Design a reconnaissance study to determine 
the following:

a. The major factors that actually affect the river-quality problem in question.

b. The anticipated range of values for each factor.

c. The amount of data needed to analyze each cause-effect relationship.

4. On the basis of steps 1 through 3 , design and implement a field and laboratory datacollection program at an intensity appropriate to adequately assess the problem.

This approach is both comprehensive and flexible. It directs a delineation of data needs, the full use of existing data and, where necessary, the development of a carefully designed program for collection of new data.

\section{MATCHING METHODS AND DATA PROGRAMS \\ TO ASSESS SELEGTED PROBLEMS}

The remainder of this paper examines the four previously described river-quality problems in terms of the methods chosen to assess each problem and the approaches used to identify, collect, and collate the required data. The discussion focuses on (1) the criteria for selecting and applying the assessment methods and (2) the development of each data program. The detail of presentation is provided to enable readers to follow the stepby-step development of functional rationales. The order of presentation is designed to contrast the three methods of assessment and the four data programs.

\section{DISSOLVED-OXYGEN DEPLETION}

THE METHOD-MATHEMATICAL MODELING

Mathematical modeling provides a potential to quantify the cause-effect relationships that give rise to DO problems. The potential exists because (1) a sound theoretical and empirical basis exists for writing the necessary equations, (2) the data required for calibrating and verifying a practical and reliable model can be collected, and (3) proven techniques are available for analyzing raw data to obtain model coefficients. Mathematical models are usually preferable to other methods of studying DO problems because they are capable of providing the most quantitative analysis of critical relationships. They, therefore, represent the best available approach for predicting the possible impacts on DO of alternatives for future river-basin development. The predictive ability is essential because, at present (1976), DO is the most important parameter for managing quality in the majority of the Nation's rivers.

In concept, mathematical modeling of DO provides a powerful tool for problem solving to resource planners and managers, pollution-control officers, and governmental decisionmakers. However, with notable exceptions, these groups have failed to accept DO models as practical planning tools and have viewed river-quality models with considerable mistrust. This failure to accept and trust models may stem from the fact that some river-quality models have not been based on sufficient data nor effectively applied to real planning and management situations. Similar conclusions have been cited by other investigators, including Lombardo (1973); Weber, Kisiel, and Duckstein (1973); and Velz (1970).

This section will describe considerations vital to the formulation and use of a practical DO model for the Willamette River (see Hines, Rickert, McKenzie, and Bennett, 1975).

\section{MODEL CONFIGURATION}

General applicability to any river is sometimes an important objective of a DO model. Usually, models with this objective are sophisticated in configuration because they must have dynamic mathematical components and model parameters for simulating the common deoxygenation and reaeration phenomena, plus photosynthesis, nitrification, and benthal oxygen demand. In addition, the model must account for extreme ranges in river discharge, hydraulic conditions, river temperature, and other environmental factors. The resulting sophisticated model configuration seldom is justified by environmental conditions or planning and management needs in any particular basin.

The essence of applied DO modeling is to fit the model to the river rather than the river to the model. This was done for the Willamette River by making a premodeling reconnaissance to determine the most reasonable level of model sophistication. The reconnaissance was designed to provide preliminary information on mixing phenomena, waste-loading characteristics, riverflow patterns, expected ranges of model parameter values, and the presence or absence of nitrification and benthal oxygen-demanding deposits. Insight into such factors prior to formulation of 
the model greatly enhanced the compatability of the model with conditions actually occurring in the river.

\section{CRITICAL PERIOD}

The size and complexity of most river basins limit the capability for modeling all seasonal changes of the DO regimen. There is a mystique, perhaps fostered by reliance on general-case models, that because seasonal changes in DO occur, a useful model must simulate all these changes. In reality, attempts to formulate such models may obscure important objectives, waste money and time, and provide useless results.

In many river basins there is a critical seasonal period, controlled by cyclic hydrologic processes, at which a DO model can be aimed. In the Willamette River basin, planning and management decisions have been (and are being) predicated almost entirely on stressed DO conditions that occur only during the low-flow, high-temperature summer period. Thus, for planning and management purposes, a DO model of the Willamette needs to simulate only those conditions that occur during a 2- to 3-month period.

The critical-period rationale for modeling DO in the Willamette offered several advantages. First, the critical conditions occur during hydrologic periods of steady-state flow. This means there was no practical need for dynamic-model components. Steady-state, plug (nondispersive) flow was realistically assumed, and only small ranges in associated variables and processes needed to be considered. Second, the critical lowflow conditions are a function of basin hydrology, as modified by reservoir-release schedules, and recur on a cyclical basis. Thus, it was possible to evaluate recurrence probabilities of discharge levels (see "Reservoir-Simulation Model") and to relate these to predictions from the DO model. Third, data needs for calibration and verification of the model were greatly reduced. Because only a short period of the year needed to be studied, the field program was intensive enough to provide a high degree of data reliability.

\section{CALIBRATION AND VERIFICATION}

Calibration is the procedure whereby model parameters are adjusted so that model outputs (for a particular set of input data such as streamflow, temperature, and waste loads) approximate a set of observed river-quality data. The ranges within which parameters can be realistically adjusted are important to the credibility and utility of the model.

Modelers are often faced with poor data for calibration and, as a consequence, rely heavily on mathematical-optimization techniques to quantify model parameters. The optimization process involves two steps. First, a numerical range is established within which each model parameter can vary. The range, which is typically quite large, is usually obtained from a literature review. Second, numerous computer runs are made, and values for each parameter are simultaneously varied within the established ranges. During the computer runs, a least-squares procedure is used to obtain a "best fit" of model outputs to a set of observed river-quality data. The modelparameter values resulting in the "best fit" are considered to be the optimum values. Often these values are not checked independently for realism within the actual river system.

When done in the described manner, calibration becomes a computerized "curve fitting" process instead of a "fine tuning" process governed by scientific understanding and direct river experience. Unless the computed values happen to be closely similar to actual values in the river, the resultant model will be incapable of reliably predicting future river-quality conditions.

In the Willamette study, the schedule was organized so that numerical values for critical parameters could be established by independent field and laboratory study. For example, the range of deoxygenation rates was established by a carefully conducted BOD sampling and analysis program. Similarly, reaeration rates, though not directly measurable, were approximated for each reach through careful collation of flow and channel-geometry data. In addition, all major underlying assumptions (for example, homogeneous mixing, plug-flow) of the model were checked for reasonableness.

Verification is the essential step for substantiating the predictive capability of a river-quality model. The procedure involves the use of a calibrated model (that is, the same model-parameter values developed during calibration) and a new set of observed data. Some of the new data establish the boundary conditions necessary to "start" and "run" the model. The rest of the data serve as an independent set of observations for comparison with model predictions (outputs). 
If the model predictions are acceptably close to the independent observations, the model is considered verified. If the predictions are not acceptably close or if model-parameter values must be juggled to make the model "fit" the observations, the verification has failed. The acceptably close criterion should be established before verification and can, in part, be based on the "goodness of fit" obtained during calibration as defined by the standard error of estimate (see Dawdy, 1969).

To provide a sound planning model, the data used in verification must not include any data used to calibrate the model or to develop its parameters. Moreover, as noted above, the acceptably close criterion for verification should be established before verification. Both these needs were met in the Willamette DO model by the intensive collection of field data during the summers of successive years. Data from one summer was used for calibration, data from the other, for verification.

DATA PROGRAM

DEFICIENCIES OF MONITORING

AND SURVEILLANCE DATA

In many basins, the existing river-quality data base has been compiled largely through pollution-monitoring and surveillance programs. Such programs are usually concerned with determining compliance with State and Federal water-quality standards or with attempts to discern trends. Monitoring and surveillance programs usually involve routine grab sampling and rigid temporal and spatial guidelines. For example, in a particular river, 10 sites might be designated for sampling once or twice a month (commonly during daylight hours only on weekdays for temperature, $\mathrm{DO}, \mathrm{pH}$, specific conductance, alkalinity, turbidity, BOD, and coliform bacteria). Periodic samples may be collected for other selected constituents such as nitrogen and phosphorus. Continuous monitors for temperature or $\mathrm{pH}$ might also be operated at one or two sites.

Attempts are often made to use monitoring and surveillance data for calibration and verification of applied DO models. Unfortunately, such data are usually poorly suited for these purposes. This lack of suitability stems from several factors (Hines, Rickert, McKenzie, and Bennett, 1975):

1. Correlative data on hydrology and, especially, waste discharges are seldom determined. As a result, most monitoring and surveillance data indicate effects rather than provide insight into causes. A river-quality model can be structure imitating and predictive only if cause-effect relationships are quantitatively established.

2. Monitoring programs usually collect limited grab samples at widely dispersed sites under a wide variety of conditions. Such data rarely provide quantitative knowledge of reach-to-reach, cross-sectional, and diurnal (diel) variations. This is particularly true for a nonconservative dynamic variable such as DO.

3. The relationship between discharge and time of travel is seldom known or is overlooked in the planning of monitoring programs. Therefore, results obtained from individual sites represent a synoptic picture of the river only if samples happen to be collected during a long-term, steady-state flow condition and at the same time of day. This is rarely the case.

4. The inherent sampling and analysis errors for river-quality variables are relatively large. Consequently, to develop an applied DO model, a number of sample sets are necessary to define an index of variability.

\section{ROLE OF EXISTING DATA}

In spite of the factors listed above, existing monitoring and surveillance data can often be useful for designing intensive studies of riverquality phenomena and for providing checks on modeling predictions. The utility of existing data for these purposes (assuming the appropriate variables were sampled) is determined by several conditions: (1) the period of record, (2) collection frequency, (3) location and number of sampling stations, and (4) the ease with which the data can be segregated and collated in relation to river hydrology. The segregation and collation are necessary to distinguish the effects of man from the natural variabilities in quality that result from temporal and spatial changes in hydrology.

Analysis of existing monitoring data for the Willamette River did provide significant insight into conditions surrounding DO depletion. The analyses indicated (1) the general magnitude of DO depletion (as much as 40 percent depletion of DO saturation), (2) the affected reaches of the river (the lower $80 \mathrm{mi}(129 \mathrm{~km})$ ), (3) the yearly period of most severe DO depletion (July-August), 
and (4) the fact that summer flow was effectively steady-state and greatly augmented by reservoir releases. This information provided the background for development of a reconnaissancelevel study.

PREMODELING RECONNAISSANCE

The reconnaissance-level study was made to determine (1) river mixing and flow patterns, (2) waste-loading characteristics, (3) preliminary information on the presence or absence of nitrification and benthic oxygen-demanding deposits, and (4) expected ranges of model-parameter values.

Results of the survey indicated that several major changes had occurred since 1951 and 1960 when Velz $(1951,1961)$ studied the DO regimen of the Willamette: BOD loadings were much lower and more uniform because of basinwide secondary treatment; river deoxygenation rates were much lower; large benthal deposits were absent except in Portland Harbor; and riverchannel geometry, and thus detention time and reaeration rates, had been affected by dredging.

Conversely, one important condition remained unchanged: The river was still well mixed in most reaches. The preliminary results also indicated that nitrification was not significant, but the data were collected in the spring before the onset of high-temperature conditions. Subsequent data collected during July and August showed that nitrification was a dominant factor in the summertime DO regimen.

The findings of the reconnaissance indicated that a simpler model configuration could be used than was originally anticipated. The results also provided a sound basis for the design and implementation of an efficient data-collection program for calibration and verification.

DATA PROGRAM FOR CALIBRATION AND VERIFICATION

The goals of the intensive data-collection program were (1) establishment of cause-effect relationships for each process that affects DO and (2) independent evaluation and quantification of each model parameter and assumption. The resultant program included eight major elements as follows:

1. General hydrologic characteristics of the river were determined (table 3 ) and compared with existing DO records. As expected, the deep, slow-moving Tidal Reach and "Newberg Pool" (see fig. 4) exhibited significant summertime depletion of DO. In addition, the shallow, swift-flowing Upstream Reach showed significant DO depletion beginning in the vicinity of Salem. Above Salem, projected pollutional loadings and the physical characteristics of the river (high velocities, geometry indicative of rapid reaeration) suggested that DO depletion would not become a problem in the foreseeable future. Accordingly, only the lower part of the river beginning near Salem was studied in a manner intensive enough to provide a suitable data base for DO modeling.

Selection of field-sampling stations was based on (1) locations of waste discharges and tributaries, (2) locations of stream gages, (3) information on river mixing (obtained in the reconnaissance study), (4) times of travel, and (5) availability of boatlanding sites. Nearly all sampling was done from boats to avoid the possible influences on flow and local river quality that might result from bridges or other in-stream structures.

2. Each modeling reach was studied intensively for 2- or 3-day periods during the JulyAugust steady-state, low-flow periods of 1973 (see fig. 2) and 1974. During each study, 5 to 10 stations were sampled in each reach from dawn until dusk. Every 2 hours, DO and water temperature were measured using a meter and field probe, and where warranted by indications within the sections, horizontal and vertical traverses were made. River BOD samples were collected every 2-4 hours. Samples to determine BOD loading were collected daily or at more frequent intervals from tributaries and from all municipal and industrial wastetreatment plants. Collection of BOD samples began 2-7 days before each study, depending on traveltime through the reach.

3. During the study period, several recording monitors were operated continuously in each reach to determine diel variations in temperature, DO, specific conductance, and $\mathrm{pH}$. Algal photosynthesis and respiration were discernible from the data at several sites.

4. All river- and waste-BOD samples were incubated for 20 days, and DO measurements were made at frequent intervals to permit 
determination of $B O D$ rate curves and ultimate $\mathrm{BOD}\left(\mathrm{BOD}_{\mathrm{ult}}\right)$.

5. The possibility of nitrification was evaluated by (a) running inhibited (Tuffey, 1973) and noninhibited BOD's and, during several studies, by (b) analyzing river and wastewater samples for ammonia-nitrogen, nitrite-nitrogen, and nitrate-nitrogen.

6 . The significance of benthal oxygen demand was evaluated by sampling bed materials in areas that had historically contained sludge deposits and by examining results of vertical DO traverses at numerous cross sections.

7. Refined calculations of time-of-travel and reaeration rates were made for short subreaches of the river using detailed crosssectional geometry $(200-1,000 \mathrm{ft}(60-300 \mathrm{~m})$ intervals) data obtained from the U.S. Army Corps of Engineers. New cross-sectional data were obtained by echo sounding in reaches where there was reason to suspect recent changes in channel geometry.

8. Black-and-white and color-infrared photography of the main stem of the Willamette was obtained from the Corps of Engineers and from the Earth Resources Assessment Project of the National Aeronautics and Space administration (NASA). The photography was used, in conjunction with field observations, to examine river morphology and other physical factors.

RATIONALE FOR THE DATA PROGRAM

The program was designed to provide reliable data on the major cause-effect relationships that affect DO depletion. Emphasis was placed on obtaining data for direct calculation of required loading parameters and model coefficients. This emphasis was made to avoid reliance on literature values, arbitrary guidelines, and the estimation of model coefficients by computerized curve fitting.

All loading data were determined by analysis of waste-water and tributary stream samples collected specifically for the study. No use was made of existing data, nor were any loadings estimated from production or population records. As the municipal and industrial waste waters received secondary treatment, $\mathrm{BOD}_{\text {ult }}$ loadings could not be determined by applying a rule-of-thumb constant to 5-day BOD $\left(\mathrm{BOD}_{5}\right)$. Thus, all carbonaceous loadings were obtained by running 20-day
BOD's $\left(\mathrm{BOD}_{20}\right)$ and using the resultant rate curves for calculation of ultimate demands. The nitrification inhibitor (Tuffey, 1973) was used because most effluents and several tributaries contained appreciable concentrations of ammonia-nitrogen. The actual ammonia loadings were determined by direct analysis of aliquot samples.

Data were collected to permit calculation of the coefficients for deoxygenation, reaeration, and nitrification. At least $15 \mathrm{BOD}_{20}$ rate curves were determined at each sampling station for calculation of river-deoxygenation coefficients. The detailed channel-geometry data were assembled so that reliable reaeration rates could be calculated for each subreach of the river. Similarly, the synoptic, in-river data on ammonia decay and nitrate generation were collected to permit calculation of nitrification rates on a reach-by-reach basis.

The horizontal and vertical traverses for DO, temperature, and BOD were made to determine if samples from the centroid of flow were representative of the station cross sections. Only cross sections that reconnaissance data indicated were well mixed were sampled. As a result, $\mathrm{BOD}_{20}$ levels seldom varied significantly either horizontally or vertically within the cross section. However, vertical variations in DO contents were usually observed owing to photosynthetic activity. The continuous-monitor records of DO and temperature were collected to estimate the impact of algal activity on river $\mathrm{DO}$. The continuous DO curves were used to calculate net productivity according to the method developed by Odum (1956), as modified by Slack, Averett, Greeson, and Lipscomb (1973).

Calibration and verification have been completed (1976), and the model has been used to predict the impacts on $\mathrm{DO}$ of various alternative plans for river-quality management (Rickert, Hines, and McKenzie, 1976).

\section{IMPACT OF LAND-USE ACTIVITY ON EROSION AND RIVER QUALITY}

THE METHOD-INTERPRETIVE MAPPING BASIS

A new procedure was applied in the Willamette River basin to define the relationships between terrain properties, land-use activities, and erosional problems. The procedure was based on in- 
terpretive mapping and derived from approaches used to delineate erosional problems in the San Francisco Bay region (Brown and Jackson, 1973, 1974).

The premises of the procedure were as follows: (1) Terrain properties determine the potential erodibility of land in its natural state, (2) landuse activities represent cultural disruptions of terrain surfaces, and (3) different combinations of terrain properties and land-use activities result in different types and severities of erosional problems. The procedure was used to produce an erosional-province map through the integration of information or land-use activities, critical terrain factors, and existing erosional-depositional features. Development of the map is illustrated by steps 1 and 2 of figure 7 . The two illustrated steps actually involved a sequence of three discrete steps:

1. Identification of land-use activities. This in-

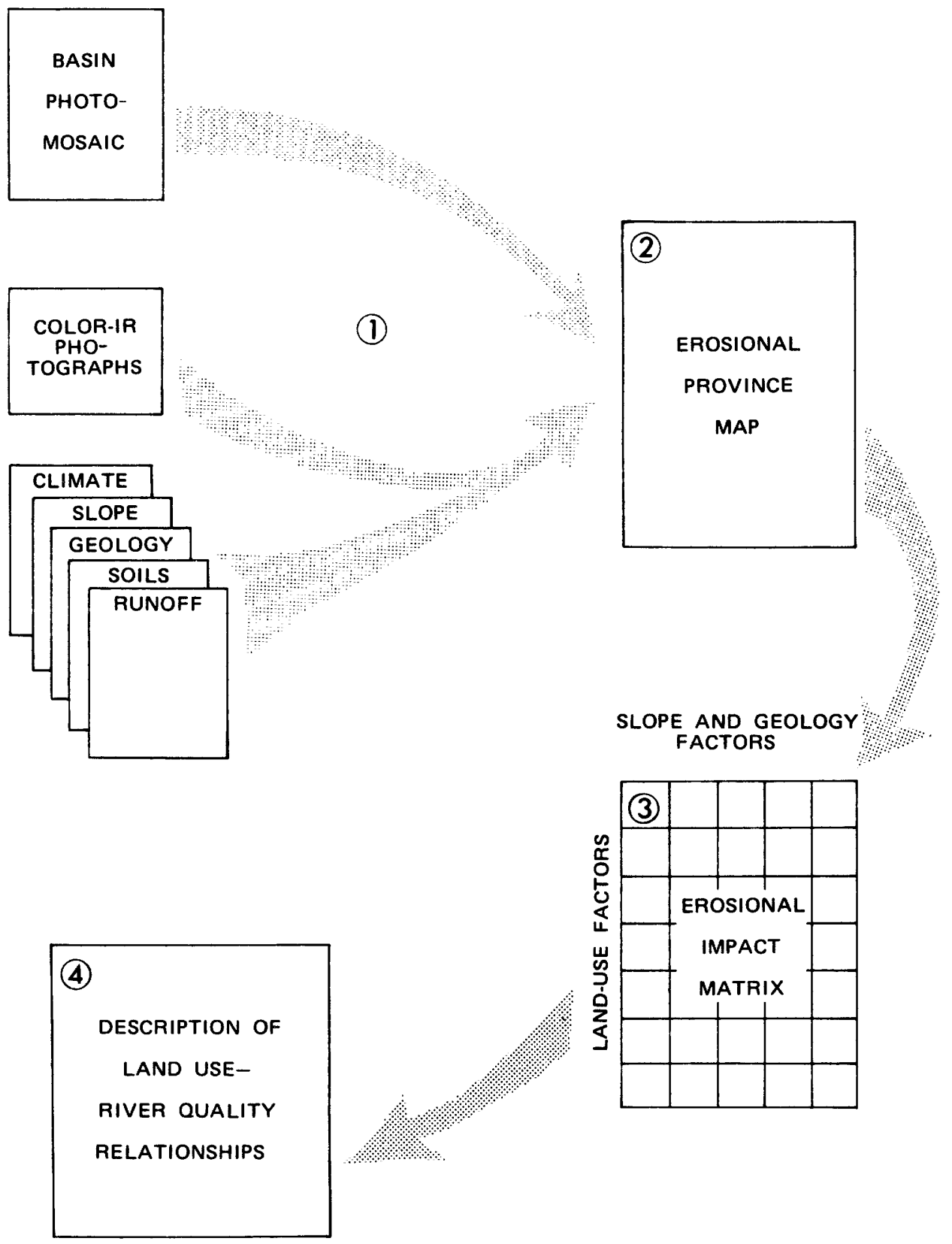

Figure 7.-Process of assessing the impacts of land-use activity on erosion and river quality. 
volved preparation of a photomosaic base from aerial photographs at a scale suitable for recognition of natural and altered surface-cover conditions. The observed cover conditions were then correlated with actual land-use activities as identified from fieldchecked interpretation of stereomagnified, false-color-infrared (IR) aerial photographs. In the Willamette River basin, surface cover provided by natural vegetation is normally dense enough to prevent serious erosional problems (Willamette Basin Task Force, Appendix G, 1969). Thus, severe erosional problems are caused primarily by those activities of man that disrupt the natural surface cover.

2. Collation of the critical physical factors that control terrain-surface stability. For the Willamette River basin, the critical regional scale factors are slope and geology. The collation involved development of criteria to evaluate the relative role of each factor, followed by preparation and visual integration of overlay maps to delineate (on the photomosaic) distinctive "erosional provinces." All areas mapped as a given province have similar terrain characteristics and, where unaffected by man, have similar potentials to erode or to receive sediment.

3. Mapping of erosional-depositional features. High-altitude, false-color-IR photographs of the basin were scanned under stereomagnification to locate distinctive erosionaldepositional features. Next, the nature of each feature (for example, gully, landslide, slump, streambank erosion) was determined through field-checked photointerpretation, and then mapped by symbol on the photomosaic base.

The completed erosional-province map provides a means for comparing the erosional-depositional features that exist in the basin as a result of the interaction between terrain properties and landuse activities.

\section{PRESENTING THE RESULTS}

The erosional province map contains information that is important to resource planning, but in a form that is difficult to apply. To overcome this difficulty, an erosional-impact matrix was devised to synthesize the information into an easyto-use format (figure 7, step 3).
The matrix was produced by listing erosional weighting factors for land-use activities as rows and additional sets of factors for slope and geology as columns. The body of the matrix is composed of numerical, erosional-impact ratings (ranging from $<10^{3}$ to $>10^{3}$ ) resulting from the product of the weighting factors for land-use activity, slope, and geology.

The magnitude of the numerical ratings indicates the relative seriousness of erosional problems likely to develop under the various combinations of erosional provinces (as defined by slope and geology) and land-use activities. Although the products are numerical, the ranking methodology limits their use to providing rough estimates of erosional impacts. To account for this limitation, the full range of numerical rankings is divided into relative-seriousness categories of slight, moderate, and great.

The effect on river quality of erosion and deposition depends on the kind, number, and extent of erosional-depositional disturbances and their proximity to the river. Ideally, a second type of matrix could be used to depict the relative severity of potential river-quality problems that might result from the erosion and deposition associated with different land-use activities. This concept was investigated for the Willamette River basin, but existing data were insufficient to define all the relationships, and time constraints precluded collection of needed new data over so large an area. However, the river-quality impact matrix may be considered for future studies of smaller areal extent. For the present study, qualitative discussions are used to trace important relationships between land-use activity, erosion and deposition, and the consequent impacts on river quality (fig. 7, step 4).

The sequence of maps, matrices, and discussions can provide information in any basin that is vital to land-use and river-quality planning. The principal attributes are (1) graphic depiction of the relationships between terrain properties, land-use activities, and erosional impacts; (2) provision of information to resource planners in a ready-to-use format; and (3) amenability to regular updating to provide information under rapidly changing conditions.

\section{DATA PROGRAM}

Production of the erosional province map required (1) false-color-IR aerial photographs, (2) 
black-and-white aerial photographs for construction of an up-to-date photomosaic base, and (3) data on an array of natural terrain properties.

\section{FALSE-COLOR-IR PHOTOGRAPHY}

The false-color-IR photographs required for the study were taken at high altitude $(65,000 \mathrm{ft})$ by NASA and range in scale from $1: 32,500$ to 1:130,000. The photographs have high resolution and come on continuous overlapping transparencies to facilitate stereoscopic viewing.

The false-color-IR photographs allow a distinction among many important land-surface features not possible from other photography; for example, timber, other heavy vegetation, and crops appear in various shades of red; dirt roads, denuded areas, and erosional features such as landslides appear white; nonvegetated urban areas commonly appear blue gray; and water appears bright blue. These color-enchanced distinctions provide a powerful basis for quick synoptic examination of land-use activity and for locating and describing erosional-depositional features.

\section{PHOTOMOSAIC BASE}

An up-to-date photomosaic base was needed to permit recognition of major surface-cover conditions and as a compilation base. The mosaic posed questions concerning scale, method of production, and need for enhancement.

The question of scale was directly related to the size of the Willamette River basin, which, as previously noted, is roughly rectangular, with a north-south length of about $150 \mathrm{mi}(240 \mathrm{~km})$ and an average east-west width of about $75 \mathrm{mi}$ (120 $\mathrm{km}$ ) (fig. 1). Selection of a suitable scale required the balancing of two factors: (1) a scale large enough to provide sufficient detail to permit recognition of surface-cover conditions and to define erosional-depositional features and (2) a scale small enough so that the entire basin could be mapped on three or four sheets of convenient size. The second factor was important because the objective of the mapping was to provide a synoptic view of erosion potential throughout the entire basin. The scale of the NASA black-and-white photography was 1:130,000, and this was selected as a reasonable compromise. This is similar to the scale of $1: 125,000$ used for regional mapping of the nearly $7,000-\mathrm{mi}^{2}\left(18,000 \mathrm{~km}^{2}\right)$ area in the San Francisco Bay Region Environment and Re- sources Planning Study (U.S. Geological Survey, 1970).

Considerable thought was given to the pros and cons of constructing a fully controlled, rectified mosaic versus a semicontrolled mosaic. A completely controlled, rectified mosaic would have provided the best possible base for compilation and for accuracy of the final product. However, estimates of relative times and costs for construction greatly favored the semicontrolled base. Moreover, the original NASA photographs were taken from such a high altitude $(65,000 \mathrm{ft}, 19,800$ $m$ ) that distortion in a semicontrolled base would be small. Also, the base would be intended only for interpretive reconnaissance, not as a basis for engineering scaling. The decision was thus made to construct a semicontrolled mosaic using photoreduced Geological Survey 15-minute quadrangle maps as a basis for control.

The third question concerned enhancement. Consideration of the desired product indicated a need for enhancement of both cultural and hydrologic features. Cultural features were enhanced through linework and titles, whereas hydrologic features were enhanced through linework, titles, and the use of color. The enhancements were made on overlays which were photographically composited with the photomosaic base.

TERRAIN PROPERTY DATA

As previously noted, erosional provinces in the Willamette River basin were delineated through the integration of data on geology and slope. However, information on climate, soils, and runoff was also collated to test delineation hypotheses and to provide a basis for discussing the resultant map. The following provides a brief synopsis of the major sources of data and the manner in which existing information was culled and collated.

\section{Cimiate}

Knowledge of climate and, in particular, the precipitation pattern in regard to type, frequency, duration, and intensity is critical in determining the potential runoff and erosion that can occur on a terrain surface. Detailed climatic data were available for only a few scattered locations in the Willamette River basin. However, an existing isohyetal map (Willamette Basin Task Force, Appendix $B, 1969$ ) provided useful information on 
generalized, basin-wide patterns of average annual precipitation. For the regional scale of this study $(1: 130,000)$, the generalized data were considered sufficient for developing precipitation criteria as a basis for evaluating the importance of this factor on erosion potential.

\section{SLOPE}

Slope is the most important single factor affecting land-surface stability because it determines (1) the susceptibility of rock and soil to downslope mass movement and (2) the potential rate of runoff and thus the potential for fluvial erosion (Leopold, 1968). Generalized slope information was available for most of the Willamette River basin from the Oregon State Water Resources Board (1969). The slopes were grouped in general categories, and for most areas this was sufficient. An alternative source, used only to a limited extent, was the slope information that could be derived from standard topographic maps of the U.S. Geological Survey. In addition, the stereoscopic viewing of the false-color-IR photographs allowed qualitative slope analysis at any specific location.

\section{Geology}

A complete large-scale geologic map of the basin was needed to accurately delineate exposures and to classify the various rock units according to erosional characteristics and slope stability. Most of the existing information was available from U.S. Geological Survey publications, supplemented by data from the State Department of Geology and Mineral Industries. The scales of existing maps ranged from 1:24,000 to 1:500,000, a 20 -fold difference. In addition, different maps used different letter symbols to denote the same geologic formations. The cullingcollation procedure consisted basically of three steps: (1) development of a consistent geologic mapping system specifically keyed to isolating erosion potential; (2) discussion and crosschecking to determine which maps were the most accurate; and (3) where two or more accurate geologic maps covered the same area, selection of that map closest to the scale of $1: 130,000$ which covered the largest area.

\section{SoILs}

Soils maps are needed to delineate characteristics important to erosional potential such as land- form position, soil texture, and infiltration capacity. Soils maps for various parts of the basin at various scales were available from the Soil Conservation Service, the U.S. Forest Service, the Agricultural Experiment Station at Oregon State University, and the Oregon State Water Resources Board. The culling-collating process was similar to that for geology. An additional difficulty existed because the maps were prepared for different purposes and grouped soils according to different characteristics. In some cases, the units had to be broken into subunits and recombined.

\section{RUNOFF}

Data on surface runoff and streamflow were available from the U.S. Geological Survey in the form of basic-data reports and from a hydrologic atlas at a scale of 1:500,000 (Oster, 1968). These data, in conjunction with basic information on geology and soils and the photointerpretation of landforms, were used to estimate the perviousness and slope stability of exposed geologic units.

\section{COMPARATIVE ROLES OF EXISTING AND NEW DATA}

The erosional study consisted of (1) culling and collating existing data on terrain properties and (2) interpreting new reconnaissance-type data made available in high-altitude photographs. Large scale photographs could have been obtained from NASA for more detailed interpretations of land-use activities and erosionaldepositional features. However, this potential was not pursued because data on the various natural features of the terrain did not exist in comparable detail nor could such data be collected during the time span ( $2 \frac{1}{2}$ years) of the study. Thus, the scale and scope of existing terrain data are the limiting factor in the detail of the regional erosional-province map.

\section{POTENTIAL FOR ALGAL PROBLEMS}

\section{INFEASIBILITY OF MATHEMATICAL MODELING}

Concern about the potential for algal problems led to a search for a suitable assessment method. An applied eutrophication model would have been ideal. However, at present, the complex eutrophication process is so poorly understood (Hines, Rickert, McKenzie, and Bennett, 1975) that it is virtually impossible to develop applied models capable of valid quantitative predictions (McGauhey, 1974). Certainly, many years of 
fieldwork would be required to obtain data adequate to model the sources, sinks, and transport mechanisms of algal nutrients. Even more data would be needed to quantify the relationship of algal growth to nutrient availability and to other environmental factors. These considerations indicated it would be impossible to obtain adequate data to formulate, calibrate, and verify a practical eutrophication model within the $21 / 2$ year time span of the study.

Instead of a predictive model, a qualitative descriptive study was designed to provide insight into the potential for excessive algal growth.

\section{THE METHOD-DDESCRIPTIV'E ASSESSMENT}

Many river-quality problems exist that presently cannot be assessed through modeling, mapping or the use of other specific methods. However, resource-planning information can be obtained for most of these problems through descriptive assessment. Descriptive assessment is basic to all other methods because it is the fundamental basis of scientific endeavor.

Although basic to modeling and mapping, descriptive assessment differs in the mode of approach. The other methods proceed primarily by snythesis, whereas descriptive assessment depends primarily on analysis. For example, in modeling, we attempt to obtain the desired information by adding together various building blocks and combining them into a more highly organized structure; this is synthesis. In contrast, the approach to descriptive assessment is to separate a large system into its component parts to provide clues to the problem; this is analysis.

As used in the Willamette study, descriptive assessment embodied problem definition, devising of hypotheses, collection and analysis of data, and exclusion of disproved hypotheses. For some problems, the cycle was repeated several times to refine the remaining possibilities. The final results are qualitative, because they provide no numerical predictions, but rather a general knowledge of the ways in which environmental and cultural factors combine to control riverquality phenomena.

The basic working hypotheses for the Willamette algal study were:

1. Nuisance algal growths will develop provided the loading of major nutrients to the Willamette remains constant or increases, and loading ratios remain in proportion. This, in turn, is based on the hypothesis that certain undesirable algae (mostly blue-greens and certain greens) compete better than desirable species (most diatoms and green algae) under a condition of low carbon concentrations and high nitrogen and phosphorus concentrations.

2. Algal growth is limited by a scarcity of certain trace elements.

3. Nuisance algal growths are prevented by low water temperatures.

4. Nuisance algal growths are prevented by short detention times of water in the Willamette.

5. Nuisance algal growths are prevented by high summertime turbidities.

\section{DATA PROGRAM}

ROLE OF EXISTING DATA

Available data on physical characteristics (fig. 4 and table 3 ) were analyzed to determine which reaches of the river are most susceptible to possible algal problems. Conditions of high temperature and slow-moving, slowly mixing water would seem to be most favorable to the nuisance forms of green and blue-green algae. Thus, should nuisance algal growths develop in the river, they would probably occur in the Tidal Reach and the "Newberg Pool."

Existing water-quality data were examined with regard to (1) nutrient loading, (2) nutrient concentrations in river water, (3) the types and numbers of algae, and (4) physical factors such as temperature and light availability. The data provided a good idea of what to expect for the loading and, as previously noted (see "Algal Problem Potential"), for the river concentrations of carbon, nitrogen, and phosphorus. No information was available on the loading and availability of minor algal nutrients.

Excellent temperature data were available, but the sparse data that did exist on algal species, algal quantities, and light penetration were from the mid-1960's when the river still received some untreated and primary treated waste waters. The relevance of the data to 1973 conditions was questionable, so a reconnaissance algal-monitoring study was immediately devised. However, the existing algal data were later analyzed in conjunction with the new information on the Willamette and with historical data from other rivers. These analyses were made to relate algal 
conditions in the Willamette to past conditions and to anticipate problems observed in similar rivers elsewhere.

RECONNAISSANCE

The reconnaissance-level work consisted of two items:

1. A plankton-monitoring network of five stations with three in the Tidal Reach (RM's 7, 12.8, and 21.2) and two in the "Newberg Pool" (RM's 35 and 50). The stations were sampled biweekly from June through September 1973 and 1974 and occasionally during other months of each year. At each station, samples were depth integrated throughout the euphotic zone at several points in the cross section. Laboratory analyses were then made of the species and numbers of algae and algal-nutrient concentrations. In situ measurements were made of $\mathrm{DO}, \mathrm{pH}$, temperature, and light penetration.

2. Periodic analyses of waste-water effluents and tributary inflows to determine the river loading of major algal nutrients.

Information obtained from this reconnaissance was used to design a series of intensive studies.

\section{INTENSIVE STUDIES}

The intensive studies were designed to document the chemical and physical conditions associated with the onset of peak algal growth and the impact of this growth on river quality. The work included the following items which were done simultaneously.

1. Intensive sampling at the five stations included in the reconnaissance network. Samples for analysis of algae and nutrients were collected at least once per day. Incident light and light penetration were measured several times each day, whereas temperature, $\mathrm{DO}$, and $\mathrm{pH}$ were monitored continuously.

2. Algal production-respiration determinations using the light- and dark-bottle DO and C-14 techniques (Slack, Averett, Greeson, and Lipscomb, 1973). These were made at several depths at the Tidal Reach stations on six different occasions.

3. Enrichment bioassays run at the same stations and depths, and by the same techniques, as the basic production-respiration tests. Treatments included enrichment with nitrogen and phosphorus (separately and in combination), mixtures of micronutrients, domestic sewage effluents, and pulp- and paper-mill effluents. The tests were run on three occasions.

RATIONALE FOR THE DATA PROGRAM

The overall data program was designed to gain insight into the factors that control the growth of algae under present river conditions. The reconnaissance studies provided information on the general availability of algal nutrients, the growing-season variations of key physical factors, and the response in terms of algal species and numbers. The intensive studies provided similar information during periods of peak algal growth. In addition, the light- and dark-bottle tests and the diel records of $\mathrm{DO}$ and $\mathrm{pH}$ measured the impact of peak growth on the river. The enrichment bioassays determined the extent to which the growth of algae was nutrient limited and the potential impact of adding higher concentrations of nutrients to the river.

The data program provided information for evaluating the working hypotheses and supplied a baseline from which trends can be established and predictions made as subsequent data become available. Sufficient insight was attained to determine which factors must be managed in the Willamette to avoid future algal problems (Rickert, Petersen, McKenzie, Hines, and Wille, 1976).

\section{TRACE-METAL OCCURRENCE}

\section{THE METHOD_DESCRIPTIVE ASSESSMENT}

Prior to this study, virtually no data existed for the Willamette River system on the content of potentially toxic trace metals in the water, sediment, and food chains. Data were so sparse as to preclude even a preliminary assessment of whether metal concentrations were low, moderate, or critically high. To partly fill this void, a descriptive assessment was designed to provide basinwide information on the concentration and distribution of trace metals in river-bottom sediments.

The objectives of the assessment were to provide (1) baseline information for future comparison and (2) a basis for determining whether the analyzed metals were present in high enough concentrations to represent an ecological threat.

The first goal was fully attainable, the second 
only partly, because scientists presently lack the ability to relate with confidence the determined concentrations of trace metals in rivers to specific potentials for aquatic organism toxicity. Instead of defining toxicity relationships, the present study developed a procedure for identifying trace metals that were present in concentrations indicative of pollution. Through this process of red flagging, specified metals were classified as worthy of more intensive study.

Formulation of the assessment involved (1) selection of a sampling medium suitable for surveying the basinwide occurrence of trace metals and (2) development of a process for distinguishing between natural and polluted trace-metal concentrations.

\section{SAMPLING MEDIUM}

Bottom sediments have two major characteristics that make them a desirable sampling medium for a reconnaissance-type study. First, fine sediments can usually be found and sampled from most reaches of most large rivers. Second, because trace metals associate strongly with particulate materials, bottom sediments act as metal integrators during periods of low-flow velocities when the riverbed is not being scoured. During such periods, the riverbed is a depository for incoming sediments, and these, as well as the sediment already in place, can serve as scavengers of dissolved metals from the passing water. Bottom sediments collected during a period of low-stable flow thus provide information on the presence of metals during the period and can be used to delineate areas of anomalously high concentrations and possible sources.

In contrast to bottom sediment, water, suspended sediment, and aquatic organisms are less desirable as a medium for conducting a synoptic, trace-metal reconnaissance. Water is, in some ways, the least desirable because a water sample collected from a flowing river represents the conditions that exist at a single instant in time. If the discharge of metal wastes is intermittent (as is often the case), downstream water samples may miss the pollution. Moreover, even with constant discharge of metals, water samples collected at distant sites may show little or no pollution because the metals could well be removed from solution by sorption onto sediment particles during downstream passage.

With intensive sampling, suspended sediment is an excellent medium for determining tracemetal occurrence during specific runoff events. However, suspended sediment is too transitory to provide a sound sampling basis for synoptic, basinwide surveys. Aquatic organisms are the focus of toxicity studies, but they too represent a poor medium for determining the basinwide occurrence of trace metals. The major drawback to their use is the improbability of finding enough of specific life stages of selected organisms at all predetermined sampling sites.

\section{DISTINCTION BETWEEN NATURAL BACKGROUND} AND POLLUTION

A process was needed to distinguish tracemetal concentrations representing natural background conditions from those caused by pollution. A two step process was developed for this purpose:

1. Plot metal concentrations in fractionated fine materials (see "Data Program") on normal probability paper according to the method described by Velz (1970, p. 522-542). Concentrations which follow a normal distribution are suggestive of natural background and all other concentrations are indicative of pollution (see Rickert, Kennedy, McKenzie, and Hines, 1976).

2. Compare the trace-metals concentrations suggested as representing natural background conditions from step 1 to published data for soils of the Willamette River basin and to worldwide averages for clays and shales. Data for fine fractions of "natural-condition soils" are available in Shacklette, Hamilton, Boerngen, and Bowles (1971) and in printouts from computerized data storage banks of the Geological Survey. Worldwide averages of metal concentrations in clays and shales are reported by Parker (1967) in a paper on the geochemistry of the Earth's crust.

\section{DATA PROGRAM}

Sampling sites were selected to provide (1) general coverage of the entire main stem of the Willamette and (2) detailed coverage of locations below possible sources of trace metals. Rivervelocity data and low altitude aerial photographs (U.S. Army Corps of Engineers, 1973) were used to determine areas where fine materials were likely to be found under low-flow conditions.

The objective of field sampling was to obtain enough fine-grained material from each site to provide a basis for laboratory analyses. In gen- 
eral, no attempt was made to sample cross sections in a detailed manner, because such sampling was not needed to meet the reconnaissance-type objectives. Samples were collected in late September 1973 after a period of more than 4 months of steady low flow. Thus, the results represent a synoptic picture of trace-metal occurrence over a period of considerable length.

The sampling network was designed to place special emphasis on the lower end of the Tidal Reach, because this is the primary depositional zone of the river. (See "Tidal Reach.") Satisfactory samples were obtained in the Tidal Reach with a Petersen dredge (Slack, Averett, Greeson, and Lipscomb, 1973) by taking and compositing two or three bites at the visual center of flow. The visual center of flow was used in preference to the center of the cross section because, in many subreaches, the channel and nearly all flow is near one bank. The sampling site for each cross section was determined by combining field observations with information contained in aerial photographs (U.S. Army Corps of Engineers, 1973).

In many upstream subreaches the riverbed is almost completely covered with gravel-sized materials. In these locations, the sampling approach consisted of searching with an Ekman dredge for small areas of fine-grained sediments. The samples, and hence the determined tracemetal concentrations, are thus unrepresentative of the channel-bed materials. However, the measured concentrations do provide an indication of the relative occurrence of trace metals in the fine sediments of each subreach. The sampling approach simply uses the fine materials in bed sediments as a natural trace-metal concentrator.

Forty-four samples were collected and aliquots of each were size fractionated so that metal concentrations could be compared to the percentages of clay, silt, and sand on a sample-by-sample basis.

The metal analyses were performed on subsamples sieved through 2-mm screens and on aliquots of $<20-\mu \mathrm{m}$ materials obtained by further fractionation of the $<2-\mathrm{mm}$ materials. The $<20-\mu \mathrm{m}$ materials contained the clay and fine silt fractions from each whole sample and were roughly comparable in grain size to clays and shales. The fractionation at $20-\mu \mathrm{m}$ thus provided a basis for comparing the trace-metal results to published geochemical data for these rock types. More importantly, the use of $20-\mu \mathrm{m}$ fractions suc- cessfully standardized the variations in metal concentrations that otherwise would have resulted from sample-to-sample differences in the proportion of fine-grained materials. The $<20-\mu \mathrm{m}$ data were proven to provide a sound comparative basis for detecting trace-metal pollution.

Metals analyses were made by two methods. Semiquantitative six-step spectrographic analysis (Myers, Havens, and Dunton, 1961) was used to scan the presence and approximate concentrations of 50 elements. This method was primarily used to determine if any of the wide array of investigated metals was present in anomalously high concentrations.

Atomic-absorption spectrophotometry was used to determine more quantitatively the concentrations of arsenic, cadmium, chromium, copper, lead, mercury, silver, and zinc (Ward and others, $1963 ; 1969)$. These eight metals were specifically selected for more quantitative analysis because they are widespread by-products of man's activities and are potentially toxic to aquatic organisms.

\section{RATIONALE FOR THE DATA PROGRAM}

The data program was designed to provide baseline reconnaissance-type information. The purpose was to collect enough samples of a suitable medium so a synoptic basinwide picture could be developed of trace-metal occurrence. In contrast to the programs for the other three project elements, no attempt was made to collect the kinds and intensities of data required to define cause-effect relationships. By applying the two step screening process to the collected data, it was possible to detect several cases of trace-metal pollution and to identify the sources (Rickert, Kennedy, McKenzie, and Hines, 1976).

\section{SUMMARY AND CONCLUSIONS}

The beginning of a comprehensive environmental assessment project is a time of many questions and few answers. The questions include all sorts of matters, such as what are the goals and objectives? With whom should we coordinate? What are the critical problems? What scientific methods should we use? How should we design the data programs? To whom should we aim the results and reports?

The initial uncertainty is normal and under- 
standable. The first task in project design is to reduce the uncertainty by carefully defining the goals and objectives. The remaining design task is to answer all other questions within a goalobjective framework that is flexible enough to permit useful change and expansion as the project evolves.

The first several months of the Willamette study were used to (1) set carefully defined objectives; (2) determine the maximum possible workload in regard to the constraints of time, funding, and manpower; and (3) to identify and meet with local, State, and Federal agencies who were interested in the conduct and potential results of an intensive assessment of Willamette River quality. By the end of the second month, the discussions clearly indicated that the goal of producing sound, adequate information on important problems would require that the study duration be expanded from 2 to $2 \frac{1}{2}$ years. Because this was a prototype project, the framework provided ample flexibility to lengthen the period of study. However, a careful examination of whether program goals and objectives can be met under initial constraints is recommended as an early step in any large-scale environmental-assessment program. This need exists because such programs are so complex and require so much information that it is virtually impossible before the study begins to define how much time and money will be needed to produce useful results. Experienced personnel can develop good initial estimates, but attainment of goals and objectives cannot be guaranteed unless initial constraints can be modified.

Following the change in schedule, discussions on the Willamette study continued until eight existing or potential river-quality problems were identified, briefly evaluated, and ranked on a priority basis. The information used to develop the priorities came from the discussions, the data records of the interviewed agencies, and hydrologic and river-quality records of the Geological Survey. Once the priorities were set, the specific elements to be included in the project were selected by combining the priority ratings with the redefined constraints of time and funding.

The next step in developing the project was to define the hydrology of the Willamette River and to determine which aspects of basin hydrology needed to be modeled as a basis for assessing the selected problems. Existing data on flow, temper- ature, and channel morphology were sufficient to provide a detailed hydrologic description of the Willamette River. The collected information was used to determine where and when to collect data for assessment of each river-quality problem. The hydrologic-modeling needs were determined to be a mathematical model for simulating reservoir releases and a hydraulic model of the Tidal Reach.

The focus of project development then switched to selection of suitable assessment methods and the design of data programs to analyze the four river-quality problems. The methods were selected on the basis of the context and complexity of each problem, availability of data and the ability to collect new data, and the degree of detail needed to provide useful results. The data programs were carefully tailored to each problem and the selected assessment method through the approach of (1) identifying data needs, (2) collating existing data, (3) collecting reconnaissancelevel data, and (4) collecting intensive data at critical times and places. Except for the tracemetal reconnaissance, the goal of each data program was to define the important cause-effect relationships that controlled the specified problem. This goal was necessary because only when cause-effect relationships were defined could assessment information be used to predict the impact of planning and management alternatives.

The design of the Willamette River Basin Study is presented in this circular as an aid and stimulus to others who are interested in riverquality assessment. The report is purposely detailed because the authors believe there is great need in the literature for open discussion of approaches, methods, and data programs for practical assessment of river-quality problems. The authors encourage other environmental scientists to conceptualize and record their approaches to resource assessment so others can build upon their knowledge and experience.

\section{ACKNOWLEDGMENTS}

We wish to acknowledge the aid and encouragement of the Non-Federal Advisory Committee on Water Data for Public Use. Our special thanks go to the members of the Advisory Committee's Ad Hoc Working Group on River Quality Assessment. During the Willamette Study, the Group included Howard B. Brown, Robert A. Canhan, 
Edward J. Cleary, Laurence R. Jahn, John E. Kinney, Walter A. Lyon, John A. Roller, and Clarence J. Velz. The authors also acknowledge the helpful review suggestions of Robert M. Beall and James C. Warman.

\section{REFERENGES}

Bennett, J. P., 1975, General model to simulate flow in branched estuaries: Proceedings Symposium on Modeling Techniques, Am. Soc. Civil Engineers, p. 643-662.

Brown, W. M., III, and Jackson, L. E., Jr., 1973, Preliminary map of erosional and depositional provinces and descriptions of sediment-transport processes in the south and central San Francisco Bay region, California: U.S. Geol. Survey Misc. Field Studies Map MF-515.

-1974, Sediment source and deposition sites and erosional and depositional provinces, Marin and Sonoma Counties, California: U.S. Geol. Survey Misc. Field Studies Map MF-625.

Council on Environmental Quality, 1973, Cleaning up the Willamette, in Environmental Quality: The Fourth Annual Report of the Council on Environmental Quality, $499 \mathrm{p}$.

Dawdy, D. R., 1969, Considerations involved in evaluating mathematical modeling of urban hydrologic systems: U.S. Geol. Survey Water-Supply Paper 1591-D, 18 p.

Gleeson, G. W., 1972, The return of a river, the Willamette River, Oregon: Advisory Comm. on Environmental Sci. and Technology and Water Resources Inst., Oregon State Univ., Corvallis, $103 \mathrm{p}$.

Harris, D. D., 1968, Travel rates of water for selected streams in the Willamette River basin, Oregon: U.S. Geol. Survey Hydrol. Inv. Atlas HA-273.

Hines, W. G., Rickert, D. A., McKenzie, S. W., and Bennett, J. P., 1975, Formulation and use of practical models for river-quality assessment: U.S. Geol. Survey Circ. 715-B, $13 \mathrm{p}$.

Hines, Walter G., Rickert, David A., and McKenzie, Stuart W., 1976, Hydrologic analysis and river-quality data programs: U.S. Geol. Survey Circ. $715-D$ (in press I.

Jaworski, N. T., Lear, D. W., Jr., and Villa, Orterio, Jr., 1971, Nutrient management in the Potomac Estuary: Environmental Protection Agency, Water Quality Office, Tech. Rept. 45, 61 p.

Leopold, L. B., 1968, Hydrology for urban land planning-A guidebook on the hydrologic effects of urban land use: U.S. Geol. Survey Circ. 554, 18 p.

1969, Quantitative comparison of some aesthetic factors among rivers: U.S. Geol. Survey Circ. 620, 16 p.

Lombardo, P. S., 1973, Critical review of currently available water-quality models: Consultants rept. to U.S. Dept. Interior, contract no. 14-31-0001-3751, 85 p.

McGauhey, P. H., 1974, Synopsis of workshop on modeling the eutrophication process, in Middlebrooks, E. J., Falkenborg, D. H., and Maloney, T. E., eds., Modeling the eutrophication process: Ann Arbor Science, p. 1-4.

Myers, A. T., Havens, R. G., and Dunton, P. J., 1961, A spectrochemical method for the semiquantitative analysis of rocks, minerals, and ores: U.S. Geol. Survey Bull. 1084-I, p. 207-229.
Odum, H. T., 1956, Primary production in flowing waters: Limnology and Oceanography, v. 1, no. 1, p. 102-117.

Oregon Department of Environmental Quality, 1970, Water quality control in Oregon: Oregon Dept. Environmental Quality Rept., 28 p.

Oregon State Water Resources Board, 1969, Oregon's longrange requirements for water: Willamette Basin General Soil Map, App. I-2, 131 p.

Oster, E. A., 1968, Patterns of runoff in the Willamette River basin, Oregon: U.S. Geol. Survey Hydrol. Inv. Atlas HA274.

Parker, R. L., 1967, Composition of the Earth's crust, in Fleischer, Michael, tech. ed., Data of geochemistry [6th ed.]: U.S. Geol. Survey Prof. Paper 440-D, 19 p.

Rickert, David A., and Hines, Walter G., 1975, A practical framework for river-quality assessment: U.S. Geol. Survey Circ. 715-A, 17 p.

Rickert, David A., Hines, Walter G., and McKenzie, Stuart W., 1976, Planning implications of dissolved-oxygen depletion in the Willamette River, Oregon, in Whipple, William, ed., Urbanization and Water Quality Control: Am. Water Resources Assoc., p. 70-84.

Rickert, David A., Kennedy, Vance C., McKenzie, Stuart W.. and Hines, Walter G., 1976, A synoptic survey of trace metals in bottom sediments of the Willamette River, Oregon: U.S. Geol. Survey Circ. 715-F (in press).

Rickert, David A., Petersen, Richard R., McKenzie, Stuart W., Hines, Walter G., and Wille, Stephan A., 1976, Algal conditions and the potential for future algal problems in the Willamette River, Oregon: U.S. Geol. Survey Circ. 715-G (in press).

Sayers, W. T., 1971, Water quality surveillance: the federalstate network: Environmental Sci. and Technology, v. 5, no. 2, p. 114-119.

Shacklette, H. T., Hamilton, J. C., Boerngen, J. G., and Bowles, J. M., 1971, Elemental composition of surficial materials in the conterminous United States: U.S. Geol. Survey Prof. Paper 574-D, 71 p.

Shearman, James O., 1976, A reservoir system model for the Willamette River basin, Oregon: U.S. Geol. Survey Circ. 715-H, 22 p.

Slack, K. V., Averett, R. C., Greeson, P. E., and Lipscomb, R. G., 1973, Methods for collection and analysis of aquatic biological and microbiological samples: U.S. Geol. Survey Techniques Water-Resources Inv., book 5, chap. A-4, $165 \mathrm{p}$.

Tuffey, T. J., 1973, The detection and study of nitrification in streams and estuaries: Ph.D. thesis, Rutgers Univ., New Brunswick, N. J., 180 p.

U.S. Army Corps of Engineers, 1968, HEC-3, reservoir systems analysis: Hydrological Eng. Center Users Manual No. 23-53, 86 p.

1973, Aerial mosaics, Willamette River, May 2, 1972 : Office of the District Engineer, Portland, Oregon, 57 p.

U.S. Geological Survey, 1962-73, Surface water records, pt. 1 of Water resources data for Oregon: Portland, Oreg., U.S. Geol. Survey, Water Resources Div. (yearly repts.).

1964-73, Water quality records, pt. 2 of Water resources data for Oregon: Portland, Oreg., U.S. Geol. Survey, Water Resources Div. (yearly repts.).

1970, Topographic map of the San Francisco Bay re- 
gion, California: U.S. Geol. Survey, scale 1:125,000, 3 sheets.

Velz, C. J., 1951, Report on natural purification capacities, Willamette River: Natl. Council for Stream Improvement of the Pulp, Paper, and Paperboard Industries, Inc., School of Public Health, Michigan Univ., Ann Arbor, $80 \mathrm{p}$.

-1961, Supplementary report on lower Willamette River waste assimilation capacity: Natl. Council for Stream Improvement of Pulp, Paper, and Paperboard Industries, Inc., School of Public Health, Michigan Univ., Ann Arbor, $28 \mathrm{p}$.

1970, Applied stream sanitation: New York, John Wiley \& Sons, Inc., 619 p.

Ward, F. N., Lakin, H. W., Canney, F. C., and others, 1963, Analytical methods used in geochemical exploration by the U.S. Geological Survey: U.S. Geol. Survey Bull. 1152, $100 \mathrm{p}$.
Ward, F. N., Nakagawa, H. M., Harms, T. F., and Van Sickle, G. H., 1969, Atomic-absorption methods of analysis useful in geochemical exploration: U.S. Geol. Survey Bull. 1289, $45 \mathrm{p}$.

Weber, J. E., Kisiel, C. C., and Duckstein, Lucien, 1973, On the mismatch between data and models of hydrologic and water resource systems: Water Resources Bull., v. 9, no. 6 , p. 1075-1088.

Willamette Basin Task Force, 1969, Main report, Willamette Basin Comprehensive Study: Pacific Northwest River Basins Comm. Rept., 155 p.

1969, Hydrology, Willamette Basin Comprehensive Study, Appendix B: Pacific Northwest River Basins Comm. Rept., 163 p.

1969, Land Measures and Watershed Protection, Willamette Basin Comprehensive Study, Appendix G: Pacific Northwest River Basins Comm. Rept. 250 p. 


